\title{
2011s-56 \\ Fair Value Accounting: Information or Confusion for Financial Markets?
}

\author{
Antonio Parbonetti, Andrea Menini, Michel Magnan
}

Série Scientifique
Scientific Series

Montréal

Août 2011

(C) 2011 Antonio Parbonetti, Andrea Menini, Michel Magnan. Tous droits réservés. All rights reserved.

Reproduction partielle permise avec citation du document source, incluant la notice (C)

Short sections may be quoted without explicit permission, if full credit, including (C) notice, is given to the source.
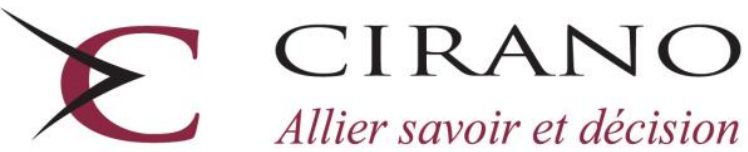

Allier savoir et décision

Centre interuniversitaire de recherche en analyse des organisations 


\section{CIRANO}

Le CIRANO est un organisme sans but lucratif constitué en vertu de la Loi des compagnies du Québec. Le financement de son infrastructure et de ses activités de recherche provient des cotisations de ses organisations-membres, d'une subvention d'infrastructure du Ministère du Développement économique et régional et de la Recherche, de même que des subventions et mandats obtenus par ses équipes de recherche.

CIRANO is a private non-profit organization incorporated under the Québec Companies Act. Its infrastructure and research activities are funded through fees paid by member organizations, an infrastructure grant from the Ministère du Développement économique et régional et de la Recherche, and grants and research mandates obtained by its research teams.

\section{Les partenaires du CIRANO}

\section{Partenaire majeur}

Ministère du Développement économique,

de l'Innovation et de l'Exportation

\section{Partenaires corporatifs}

Autorité des marchés financiers

Banque de développement du Canada

Banque du Canada

Banque Laurentienne du Canada

Banque Nationale du Canada

Banque Royale du Canada

Banque Scotia

Bell Canada

BMO Groupe financier

Caisse de dépôt et placement du Québec

\section{CSST}

Fédération des caisses Desjardins du Québec

Financière Sun Life, Québec

Gaz Métro

Hydro-Québec

Industrie Canada

Investissements PSP

Ministère des Finances du Québec

Power Corporation du Canada

Rio Tinto Alcan

State Street Global Advisors

Transat A.T.

Ville de Montréal

\section{Partenaires universitaires}

École Polytechnique de Montréal

HEC Montréal

McGill University

Université Concordia

Université de Montréal

Université de Sherbrooke

Université du Québec

Université du Québec à Montréal

Université Laval

Le CIRANO collabore avec de nombreux centres et chaires de recherche universitaires dont on peut consulter la liste sur son site web.

Les cahiers de la série scientifique (CS) visent à rendre accessibles des résultats de recherche effectuée au CIRANO afin de susciter échanges et commentaires. Ces cahiers sont écrits dans le style des publications scientifiques. Les idées et les opinions émises sont sous l'unique responsabilité des auteurs et ne représentent pas nécessairement les positions du CIRANO ou de ses partenaires.

This paper presents research carried out at CIRANO and aims at encouraging discussion and comment. The observations and viewpoints expressed are the sole responsibility of the authors. They do not necessarily represent positions of CIRANO or its partners. 


\title{
Fair Value Accounting: Information or Confusion for Financial Markets?*
}

\author{
Antonio Parbonetti ${ }^{\dagger}$, Andrea Menini ${ }^{\star}$, Michel Magnan ${ }^{\S}$
}

\begin{abstract}
Résumé / Abstract
La récente crise financière a amené une réévaluation du rôle que l'utilisation de la comptabilité à la juste valeur peut avoir sur la stabilité du système bancaire. Suite à l'intervention des organismes de réglementation des banques et de certains gouvernements, les normalisateurs comptables ont élaboré davantage les paramètres de mise en œuvre de la comptabilité à la juste valeur. Cette recherche examine si et comment l'utilisation de la comptabilité à la juste valeur par les banques américaines entre 1996 et 2009 a influencé la qualité de l'information accessible aux analystes financiers pour la préparation de leurs prévisions. Nos résultats montrent, qu'en général, plus grande est la proportion de l'actif et du passif d'une banque qui repose sur la comptabilité à la juste valeur, plus grande est la dispersion des prévisions de bénéfices effectuées par les analystes. En outre, une augmentation de la proportion de l'actif mesuré à la juste valeur est associée avec un environnement informationnel moins favorable pour les analystes (diminution dans la précision de l'information privée et de l'information publique). Cet effet est accentué pour l'actif ou le passif mesuré de niveau 3 (mesure selon modèle). Cependant, la décision récente de divulguer les niveaux d'évaluation à la juste valeur (niveaux 1,2 et 3) a amélioré la précision et le consensus des prévisions de bénéfice des analystes. Finalement, la divulgation de l'évaluation d'actifs qui sont mesurés à la juste valeur mais sur une base ponctuelle et non-récurrente semble réduire la précision des prévisions de bénéfice.
\end{abstract}

Mots clés : Comptabilité à la juste valeur, gouvernance, prévisions de bénéfices des analystes, divulgation de l'évaluation d'actifs.

The recent financial crisis has led to a critical evaluation of the role that fair value accounting may have played in undermining the stability of the financial system. Reacting to the pressures of banking regulators and governments, standard-setters have brought forward additional guidance on the application of fair value accounting. This paper examines if and how fair value reporting by U.S. commercial banks during the 1996-2009 period influences the quality of information used by financial analysts. Our results show that, overall, the greater the extent of a bank's assets and liabilities reported at fair value, the more dispersed are analysts' earnings forecasts. Moreover, as the proportion of assets measured at fair value increases, properties of analysts' forecasts become less desirable, showing a decrease in the precision of public or private information. The informational properties of fair value disclosure decrease as we move from level 2 to mark-to-model data (level 3). Nevertheless, additional analyses suggest that the disclosure of levels has been beneficial to investors as it enhanced private information precision resulting in more accurate and less dispersed analysts' forecasts. Finally, the disclosure about the valuation of assets that are measured at fair value on a non-recurring basis reduces accuracy and public information precision while enhancing dispersion.

Keywords: Fair value accounting, governance, risk management, earnings forecasts analysts, valuation of assets disclosure.

\footnotetext{
* The authors thank attendants at the European Accounting Association annual meeting (2011) and workshop participants at University of Padova for their comments and suggestions. Financial support from the Lawrence Bloomberg Chair of Accountancy (Concordia) and the Social Sciences and Humanities Research Council of Canada is acknowledged.

${ }^{\dagger}$ University of Padova, Padova, Italy.

$\$$ University of Padova, Padova, Italy.

${ }^{\S}$ Ph.D.,FCA, ASC, Lawrence Bloomberg Chair in Accountancy, John Molson School of Business, Concordia University, Associate Fellow, CIRANO. Email: mmagnan@jmsb.concordia.ca
} 


\section{INTRODUCTION}

This paper focuses on the relation between fair value accounting (FVA) and the quality of the information used by financial analysts, a key group of financial markets' participants. The study aims to address the following two questions. First, does the extent of a firm's use of fair value accounting enhances or undermines the ability of financial analysts to forecast a firm's future financial performance? Second, how does the disclosure resulting from the implementation of SFAS 157 (FASB 2006a) regarding the measurement for FV assets and liabilities affect the information environment of financial analysts?

The paper purports to contribute to the debate surrounding the use of FVA as a foundation for financial reporting. This debate, which involves professionals as well as academics, mostly revolves around FVA's implications on the relevance and reliability of financial statements. From a professional perspective, standard-setters such as the International Accounting Standards Board (IASB) and the Financial Accounting Standards Board (FASB) have been gradually raising the prominence of FVA in financial reporting, a case in point being FASB's recent proposal which would require banks to value their loan portfolios at FV (FASB 2010). While some of these changes are welcome by the investment community, their usefulness is still unclear. For example a recent survey of professional investors and analysts reveals that they prefer: 1) mixed measurement model with only short term instruments valued at fair value; 2) earnings which are free from fair value fluctuations in long term assets; 3) fair value as an input to evaluate liquidity, capital adequacy and enterprise value, but rarely as an indicator of future cash flows; 4) more detailed but not excessive disclosure (PWC, 2010). Respondents' views about FVA's lack of usefulness in estimating future cash flows is in contrast with the objective of financial reporting, as stated in the latest exposure draft jointly made by IASB and FASB. 
From an academic perspective, Barth (2007) argues that there is basically no alternative to a fair value-based model. Her position is consistent with most prior research pertaining to fair value accounting which documents its value relevance, i.e., fair value-based information in the financial statements relates with a firm's stock market value. Generally, the evidence shows that fair value information has a greater association with a firm's stock market valuation than historical cost information (e.g., Barth et al., 2001a). Moreover, there are some indications that disclosure about the measurement of fair value assets and liabilities is also value relevant with investors discounting the measurement uncertainty that accompanies movement from level 1 to levels 2 and 3 (e.g., Song, Thomas and Yi, 2010).

However, while useful in assessing the market impact of accounting standards, such value relevance research exhibits some limitations and cannot serve as a sole basis for standard development and regulatory interventions (Holthausen and Watts, 2001). For instance, Watts (2003) puts forward the view that fair value severely undermines the reliability of financial reporting and does not provide investors with a useful input to make their own projections. More specifically, fair value accounting provides managers with much accounting discretion, especially for assets and liabilities that are measured according to levels 2 and 3 inputs. Such discretion may translate into biased and less reliable financial reporting (e.g., Watts and Ramanna, 2009; Dechow, Myers and Shakespeare, 2010).

Our study relies on a sample of publicly-traded U.S. commercial banks during the 1996-2009 period, which saw the use of FV for financial instruments and just before the hit of the financial crisis the enactment of SFAS 157 and SFAS 159 (FASB 2006a,b). Using accuracy, dispersion and analysts forecasts properties as in Barron et al. (1998), we assess how FV-based information and disclosures affect the information environment faced by financial analysts. For the purpose of this 
study, we consider financial assets and liabilities valued at fair value either on a recurring or non recurring basis.

Our results show that, overall, the greater the extent of a bank's assets and liabilities reported at fair value, the more dispersed are analysts' earnings forecasts. Moreover, as the proportion of assets/liabilities measured at fair value increases, the properties of analysts' forecasts worsen, with the precision of both public and private information decreasing. In addition, the informational properties of fair value disclosure decrease as we move from level 2 to mark-to-model data (level 3). Nevertheless, additional analyses suggest that the disclosure of levels has been beneficial to investors as it enhanced private information precision resulting in more accurate and less dispersed analysts' forecasts. Finally, the disclosure about the valuation of assets that are measured at fair value on a non-recurring basis reduces the accuracy and public information precision while enhancing dispersion.

The study contributes in four ways to the debate surrounding FVA. First, starting with Bernard et al. (1995), prior research generally shows that FVA-based financial information is value relevant for stock market investors (see Barth et al., 2001a, for an early review of the evidence). However, most of the evidence relies on valuation models that show an association between FVA-based assets and a firm's stock price, which does not reveal much about the underlying process by which FVAderived information disseminates and is used by financial markets' participants to set market prices. In that regard, analyzing if and how fair value-based information translates into an improvement in investors' forecasting ability should be a critical issue for regulators, standard-setters, investors, directors and managers. Therefore we look at the analysts to capture whether "first hand" users of accounting information rely on fair value to assess companies' future performance. To the best of our knowledge, our study is the first to consider assets and liabilities evaluated at FV both on recurring and non-recurring basis. 
Second, the advent of SFAS 157 and 159 provides market participants with more detailed disclosure regarding the measurement basis for FVA assets and liabilities, i.e., levels 1, 2 and 3. However, there is an ongoing debate as to the benefits to be derived from greater transparency. For instance, such greater transparency may, in fact, bring further noise to the market since the actual measurement methodologies and inputs are not provided (Laux and Leuz, 2009). Furthermore, finer disclosure about the measurement basis for reported assets and liabilities may either help investors at large or, alternatively, only those investors and analysts with sufficient tools and background information to make sense of the disclosure (Beyer, Cohen, Lys and Walther, 2009). While FVA has been around for many years, the ability to assess the nature of its reach within financial statements (mark to market vs. mark to model) has expanded significantly in the past few years with the advent and application of SFAS 157 and 159. Since the implementation of FVA affects reported earnings, it is an open question as to whether financial markets' participants were able to effectively apprehend the new information being conveyed and integrate into their decision-making. In that regard, by being associated with an increase in public precision, additional disclosure following the adoption of SFAS 157 does seem to enhance the quality of information available to all market participants, thus contributing to the financial disclosure/information asymmetry literature (e.g., Healy and Palepu, 2001; Leuz and Verrechia, 2000).

Third, the study sheds additional light on the issue of how useful FVA information was to financial analysts in the thick of the crisis. For instance, on September 30, 2008, on the eve of the financial crisis, Citicorp's shares were trading at \$20.51. Within a few weeks, share value went down to $\$ 3.77$, a fall of $82 \%$, with the firm reporting an operating loss of $\$ 31.7$ billion in the fourth quarter, i.e., only three(3) months after September 30. Was Citicorp's fair value disclosure, or the one from any other bank for that matter, indicative of problems to come and helpful in predicting its earnings? In this regard, evidence provided in the paper suggests that as investor fear increased, as measured by volatility, increased exposure to fair value may have translated into less accurate and 
more dispersed forecasts, reflecting lower public information precision and higher private information precision. In this sense, our paper is in continuity with Laux and Leuz (2009) discussion and allows for a fact-grounded debate about the merits of FVA.

Fourth, Khan (2010) that there is a greater risk of failure contagion among banks with a higher proportion of assets and liabilities measured at FVA. Such a finding is consistent with FVA-based financial statements providing investors, regulators and auditors with relevant and timely information about a bank's underlying risks, thus allowing them to act more quickly. However, it is also consistent with FVA, especially marked to model assets and liabilities, providing firms with a mean to hide high risk positions. By examining the impact of FVA on the informational environment surrounding the firm, the study may help us better understand the contagion phenomenon documented by Khan (2010).

Finally, through IFRS 39, the IASB is distinguishing held-for-trading assets/liabilities from available-for-sale securities in terms of FVA measurement. By showing how the application of FVA affects the informational properties of these two types of assets, the study provides standardsetters with some evidence as to the merits or limitations of the proposed standard.

The rest of the paper proceeds as follows. The next section reviews the relevant literature and puts forward non-directional hypotheses. A methodology section then follows. Results are presented and discussed next. The paper concludes with a recap of its results and some implications.

\section{BACKGROUND AND CONCEPTUAL FRAMEWORK}

\section{Fair Value Accounting}

Fair value is "...the price that would be received to sell an asset or paid to transfer a liability in an orderly transaction between market participants at the measurement date..." (SFAS 157.5) (FASB 
2006a). The parties to the transaction are assumed to be willing and knowledgeable. Commercial banks' financial statements encompass fair value accounting at three different levels (re. SFAS 115, $133,157)^{1}$

First, some assets and liabilities get measured and reported directly on the balance sheet at a fair value basis. However, their impact on the income statement depends upon their initial classification by management (SFAS 115: FASB 1993). On one hand, debt and equity securities that are bought and held principally for the purpose of selling them in the near term are classified as trading securities, with unrealized gains and losses flowing directly into reported earnings. On the other hand, debt and equity securities that are considered to be neither held-to-maturity (long term) or trading (short term) securities are classified as available-for-sale securities are reported on the balance sheet at fair value but unrealized gains and losses on these securities are excluded from earnings and reported in a separate component of shareholders' equity (other comprehensive income).

Moreover, while some assets and liabilities must be reported at fair value, firms have also an option to designate further assets and liabilities as being accounted for using fair value (SFAS159). The option must be applied on an instrument-by-instrument basis and constitutes an irrevocable choice once chosen. The rationale for such an option is well described in Citicorp's financial statements: "The fair value option provides an opportunity to mitigate volatility in reported earnings that resulted prior to its adoption from being required to apply fair value accounting to certain economic hedges while having to measure the assets and liabilities being economically hedged using an accounting method other than fair value." (Citicorp's 2009 Annual Report, p. 138).

\footnotetext{
${ }^{1}$ For specialized firms (pension funds, investment banks, etc.), fair market value may apply to all assets and/or liabilities. Moreover, while SFAS 115 does not apply to unsecuritized loans, it does apply after their securitization.
} 
Second, with the advent of SFAS 157, firms must also disclose the measurement basis that they use to assign fair values to various assets and liabilities. Three measurement bases are designated and reflect the level of judgment (subjectivity) associated with the inputs to determine fair value. Level 1 assets and liabilities are measured and reported on a firm's financial statements at their market value, which typically reflects the quoted prices for identical assets or liabilities in active markets. The underlying assumption is that an observable quoted price for an identical asset or liability in an active market provides the most reliable basis for fair value measurement as it is the best proxy to reflect the price that would be received assuming a decision to sell the asset or settle the liability. However, at any given time, assets and liabilities may not trade or may not have an active market. For these cases, fair value will be inferred by relying on observable valuation inputs that reflect a) quoted prices for similar financial instruments in active markets, b) quoted prices for identical or similar financial instruments in markets that are not active, $c$ ) inputs other than quoted prices but which are observable (e.g., yield curve) or d) correlated prices. Such a measurement basis is deemed to be Level 2. For example, a 10-year bond may not trade but, if there are active markets for 8-year and 12-year bonds issued by the same entity, the value of the 10-year bond can be inferred from the estimated yield curve. Finally, certain financial instruments which are customized or have no market are typically valued by relying on models that reflect management's assumptions about economic, market an firm-specific conditions (e.g., private placement investments, unique derivative products, etc.). Such valuation is deemed to be derived from Level 3 inputs and is commonly referred as "mark-to-model” (FASB, 2006a). In other words, the objective in level 3 measurement is to infer what the price of the asset would be, if the market existed. In all cases, any unrealized gain (or loss) on financial instruments held by an institution translates into an increase (decrease) in its stockholders' equity and, consequently, an improvement (deterioration) in its capitalization ratios. 
Third, SFAS 115 allows debt securities for which an enterprise has the positive intent and ability to hold to maturity to be classified as held-to-maturity securities and reported at amortized cost.

However, if these securities suffer a decline in fair value below the amortized cost basis that is other than temporary, their accounting cost must be written down to that value and the write-down included in net earnings as a realized loss. Once written down, held-to-maturity securities cannot be written up. One may label these securities as being measured at fair value on a non-recurring basis. In other words, while most applications of fair value are earnings neutral, i.e., neither conservative nor aggressive, there are instances in which FVA can induce conservatism in a firm's financial reporting. Such FV-driven write-downs may provide a useful signal to investors and analysts.

\section{Fair Value Accounting and Financial Markets' Information Quality}

Two broad arguments characterize the debate surrounding the use of FVA in financial reporting. On one hand, extending the reach of FVA moves financial reporting into uncharted territory on three dimensions. First, there is a widespread consensus and solid evidence that financial analysts' and investors' decisions are based upon their ability to predict a firm's performance. Toward that end, they will aim to understand a firm's business model and its underlying value drivers so that they derive earnings forecasts that will then serve as inputs into a valuation model (e.g., Asquith et al., 2005; Bandyopadhyay et al., 1995). In that regard, there is evidence that accrual earnings are a useful basis to predict future cash flows, thus indicating the critical role of the income statement in financial markets (Barth et al., 2001b). In contrast, the recent trend in standard setting, which is exemplified by FVA, is to deemphasize the relative importance of the income statement, with net earnings becoming a by-product of the variation between two end-of-period balance sheets: "in measuring performance, an entity first identifies and measures its economic resources and the claims to them ... then calculates the net change in economic resources and claims other than changes resulting from transactions with owners as owners" (Excerpt from the joint IASB/FASB proposed conceptual framework, FASB 2008). The measurement sequence that is implicit from the 
proposed framework points toward the balance sheet as being the primary financial statement. However, it can be argued that a FVA-based balance sheet provides a poor platform to derive earnings projections (O’Brien, 2009).

Second, historically, financial reporting has reflected an ongoing tension between relevance and reliability (e.g., Bushman and Smith, 2001; Scott, 2008). The rationale underlying such tension is that reliable entity-specific information is critical for investors and financial analysts seeking to make forecasts as it will drive their assumptions, relevant information not being a sufficient indicator to assess a firm's future performance. However, according to many professional observers, the advent of FVA may have undermined the reliability of financial reporting (e.g., Mintz, 2008). From an academic perspective, Ramanna and Watts (2009) argue that the use of FVA provides executives with more opportunities to manage asset values and reported earnings: in contrast to historical cost, FVA relies on several assumptions about the future, many of which may not be verifiable. In financial institutions, there are serious concerns about the verifiability of level 2 and $3 \mathrm{FV}$ assets and liabilities which heavily rely on managerial assumptions. Some observers even label level 3 fair value assets and liabilities as being "marked-to-myth" (Kolev, 2008). Moreover the ability of firms to shift assets into the level 3 category (marked-to-model) has also been criticized (Saft, 2008). A recent study highlights similar concerns about the reliability of FVA information. Using a global sample of 322 banks that apply IFRS between 2006 and 2008, Fiechter and Novotny-Farkas (2011) find that while FVA information is value relevant, its pricing differs across firm-specific and institutional factors and exhibits a substantial discount during the financial crisis. They conclude that their findings raise concerns about the general reliability of fair value.

Finally, FVA may increase volatility in reported earnings, potentially providing a misleading image of underlying performance (Benston, 2008). For instance, recent evidence suggests that FVA-based information about corporate retirement plans does not dominate the current smoothing model for 
pension accounting and that there are no obvious informational advantages in moving toward a fairvalue pension accounting model (Hann et al., 2007). ${ }^{2}$ FVA-induced volatility may translate into a more difficult forecasting environment for financial markets' participants as they attempt to disentangle transitory and permanent earnings shifts. Moreover, there is evidence that financial institutions with a larger proportion of FVA-based assets and liabilities are more greatly exposed to a failure contagion risk (Khan, 2010). In other words, reliance on FVA may induce higher systemic failure risk among commercial banks.

On the other hand, the case for FVA rests essentially on its ability to reduce the information risk for investors, by providing relevant information to financial markets and enhancing financial transparency. Several studies show that FVA-based information dominates historical cost-based information in terms of value relevance, i.e., a firm's stock market value is more closely associated with FVA-based information than with historical cost information. Many of these studies have been conducted within the financial services or commercial banking industries (e.g., Ahmed et al., 2006; Barth, 1994; Barth et al., 1996; Eccher et al., 1996; Nelson, 1996). Consistent with such evidence, Linsmeier (2011) argues that it would be preferable to mandate the reporting of fair values for all financial instruments in addition to some historical cost information since fair value information alerts investors and regulators of changes in current market expectations when asset prices are declining and risk levels for financial institutions are increasing. Historical cost accounting with impairment estimates provides insufficient warning of these changes. Moreover, the advent of FVA allows investors to pierce through various earnings management schemes by financial institutions' executives: FVA essentially precludes the strategic timing of asset sales to recognize gains or losses (Barth and Taylor, 2010).

\footnotetext{
2 The latter point is difficult to ascertain. For instance, Fiechter (2010) finds evidence that banks applying the Fair Value Option with the intention of reducing accounting mismatches as well as banks that apply the FVO to financial liabilities report lower levels of earnings volatility than non-appliers. However, such reduced volatility may either reflect calm and steady underlying economic conditions or, alternatively, increased ability by executives to smooth reported earnings through strategic use of the various FVA measurement levels.
} 
With respect to transparency, the disclosure of which measurement methodologies underlie the valuation of different assets and liabilities (i.e., disclosure of FVA levels 1, 2 and 3) allows investors to differentially value them (e.g., Song et al., 2010). Overall, Barth (2007, p. 12) argues that "Although opponents of more comprehensive use of fair value have some legitimate concerns, standard setters are unaware of a plausible alternative." Moreover, arguments to the effect that the use of FVA 1) reduces the ability to predict future earnings, 2) overemphasizes relevance to the detriment of reliability and 3) induces excess volatility, can be countered in the following ways. First, FVA figures reflect market prices, or approximations of market prices. If markets are efficient, such prices or price estimates reflect unbiased expectations about underlying assets future cash flows (Milburn, 2008). Hence, with appropriate disclosure, it is possible for analysts to deconstruct the reported values and predict future earnings. Second, FVA figures, especially level 1 ones, can be deemed reliable as they reflect market prices that are readily observable. Third, volatility in FVA figures may reflect the fundamentals of a business and need to be reported, not smoothed away.

\section{Hypotheses}

In light of the above arguments, two alternative sets of hypotheses can be inferred about the impact of FVA on the quality of information available to financial markets. On one hand, consistent with the view that FVA compromises the reliability of financial reporting and induces artificial volatility, it may be inferred that the greater(smaller) the extent of a bank's exposure to FVA reporting, the lower(higher) the quality of information available to financial markets. Furthermore, within FVA assets and liabilities, the less(more) reliable the measurement basis, the lower the quality of information available (i.e., moving from level 1 to level 3 implies lower reliability). These arguments lead to the notion that as the amount of FV increases, the informational environment deteriorates. 
On the other hand, consistent with the view that FVA provides financial markets with relevant information that embeds expectations of a firm's future cash flow performance, it can be expected that the greater(smaller) the extent of a bank's exposure to FVA reporting, the higher(lower) the quality of information available to financial markets. Furthermore, within FVA assets and liabilities, the less(more) transparent the measurement basis, the lower the quality of information available (i.e., detailing levels of FVA measurement vs. no details).

Whether FV improves the information environment is an open question, therefore we do not state formal hypotheses.

\section{METHODOLOGY}

\section{Sample}

The initial sample consists of 1161 U.S. banks for which data is available from the Federal Reserve Bank of Chicago from 1996 to 2009. We also require that each bank be followed by three active financial analysts who provide earnings forecast ${ }^{3}$. As a consequence, the final number of banks included in our sample is 309 . We additionally require the availability of financial and stock market data on Datastream. The total number of bank-quarter observation is then 5963.

\section{Empirical Model}

Information environment (IE) is measured from analyst following and the properties of financial analyst earnings forecasts. We fit panel data models by using generalized least square (GLS) estimation allowing for AR1 autocorrelation structure to analyze the impact of fair value on information environment features (all $\mathrm{t}$ statistics are adjusted according to White (1980) to correct for heteroskedasticity).We use the following multivariate model to test our hypotheses.

\footnotetext{
${ }^{3}$ We consider active all those analysts that forecast annual earnings at least twice in a year in two but not in the same quarter.
} 


$$
I E_{t}=\alpha+\beta F V_{\mathrm{t}-1}+\Sigma_{\mathrm{j}} \gamma_{\mathrm{j}} \text { Control }_{j}+\varepsilon
$$

Where:

IE $\quad=\quad$ Information Environment: analysts following, accuracy (Acc), dispersion (Disp), or analyst earnings forecasts properties as in Barron et al. 1998

$\mathrm{FV} \quad=\quad$ total value of assets and liabilities measured at fair value on recurring basis divided by the total value of assets

We break down the total fair value (FV) along three dimensions. First, we split fair value between assets (FV_A) and liabilities (FV_L). Second, we distinguish among available for sale (AfS), held for trading (HfT) and loans (Loans). Third, we investigate the impact of the disclosure of fair value levels in two ways: highlighting the period after the $31^{\text {st }}$ December $2006\left(D I S_{\text {levels }}\right)$ using a subsample from 2004 to 2009 and modelling the impact of the proportion of level 2 (L2) and level 3 (L3) on total fair value. In the former case we identify a three year window among the first quarter 2007 that correspond to the first quarter in which bank has to disclose to the Federal Reserve Bank of Chicago the amount of assets and liabilities measured at fair value that belong to Level 2 and Level 3. In the latter case, we hand collect fair value data from quarterly reports for a subsample of 150 banks from $2007^{4}$. Since around $10 \%$ of the sample banks analysed voluntary disclose levels in quarterly report before the first quarter of 2008 when such disclosure becomes mandatory we exclude 2007 from our sample period. We also exclude other 19 banks due to unclear disclosure or missing values. In addition, we analyse the impact of fair value non-recurring on information environment features. In this last case, our sample consists of 131 unique banks and 606 quarterbank observations ${ }^{5}$.

\footnotetext{
${ }^{4}$ We hand collect data on fair value levels and disclosure from annual and quarterly reports, because the Federal Reserve Bank of Chicago required the disclosure of Level 1 assets and liabilities only in 2008. In addition, data on assets and liabilities measure at fair value at non-recurring basis are not provide by the Federal Reserve Bank of Chicago.

${ }^{5}$ The difference of 43 observations from our subsample is due to unclear disclosure of the amount of assets assessed at fair value on a non-recurring base or to the amount of the loss associated.
} 
We use several characteristics of information environment as dependent variables and regress them on the research variables mainly related to fair value and the disclosure of fair value. All variables are explained in detail below.

\section{Dependent Variables}

Our research strategy consists of three steps. First, we study the effect of fair value and fair value disclosure on analyst following. Second, we analyze the effect of fair value and fair value disclosure on the accuracy (Acc) and dispersion (Disp) of analysts' earnings forecasts. Accuracy is minus the absolute value of the median ${ }^{6}$ Earnings per share (EPS) estimated by analysts less the reported EPS standardized over the stock market price at the end of the year. Dispersion (Disp) is the standard deviation of EPS analysts forecast estimates over the stock market price at the end of the year.

Third, we adopt a more focused approach relying on the approach developed in Barron et al. (1998; 2002, otherwise referred as the BKLS approach). As discussed in Barron et al. (2002), changes in dispersion and accuracy can reflect both the commonality of information among analyst but also the precision in individual analyst forecasts. For example, if releasing information (e.g., earnings announcement) results in a decrease in the dispersion of analysts' forecasts, it may imply that new information reduces uncertainty and increases the commonality of information among analysts.

However, Barron et al. (1998) show that forecasts dispersion reflects not only the commonality of information among analyst but also the precision in individual analyst forecasts. As new information is released, the precision of forecasts increases over time irrespective of whether or not that information is common or idiosyncratic. As a consequence, to understand whether fair value and fair value disclosure trigger significant common or idiosyncratic information, we rely on analyst forecasts properties as originally developed by Barron et al. (1998). The method is widely used in the literature (Beuselink et al. 2009).

\footnotetext{
${ }^{6}$ Using the mean does not affect the results.
} 
According to the BKLS model, each analyst observes two signals about future earnings: a common signal that reflects knowledge shared by all analysts and a private signal available only to an individual analyst. Thus, analysts make forecasts of future earning based on the common and idiosyncratic knowledge. Although the precision of public and private information (labeled as $h$ and $s$ respectively) cannot be calculated for an individual forecast, BKLS show that with multiple forecasts, $h$ and $s$ can be measured by using the information in the aggregated forecast properties: accuracy and dispersion. Relying on the assumption that $s$ is identical across analyst Barron et al. (1998) show that:

$$
h=\frac{S E-\frac{D}{N}}{\left[\left(1-\frac{1}{N}\right) D+S E\right]^{2}}
$$

$$
s=\frac{D}{\left[\left(1-\frac{1}{N}\right) D+S E\right]^{2}}
$$

Where $\mathrm{D}$ is the dispersion of analyst forecasts for a firm, SE is the squared error in the mean forecasts and $\mathrm{N}$ is the number of analyst. Based on the BKLS model we measure the commonality of analysts' information using the across analyst correlation in forecast errors $(\rho)$. This variable captures the level of consensus among analysts and could be thought as a measure of the ratio of the precision of analysts' common information to the precision of their total information:

$$
\rho=\frac{\mathrm{h}}{\mathrm{h}+\mathrm{s}}
$$

Finally we measure the benefit of aggregating analyst forecast (Barron et al., 1998). The variable measures whether or not mean forecasts are better than individual forecasts. In other words, we calculate the difference between the squared error in individual forecasts averaged across analysts 
(U) minus the squared error in the mean forecast (SE). As a consequence the variable is $\mathrm{U}-\mathrm{SE}$, where:

$U=\left(1-\frac{1}{N}\right) D+S E$

and SE is as above.

To provide an empirical proxy for such properties, we substitute realized dispersion and squared error in the mean forecasts for the expected dispersion and error used in the BKLS model. We standardize both dispersion and SE on earnings before extraordinary items per share but using stock market price at the year end as deflector does not change the results. In line with Gu (2005) we use the square root transformation of the analysts' forecast properties.

\section{Fair Value Variables}

Our main fair value variable is the proportion of the sum of assets and liabilities on total assets (FV). We break down the total fair value (FV) along three dimensions.

First, we split fair value between assets (FV_A) and liabilities (FV_L).

Second, we distinguish among available for sale (AfS), held for trading (HfT) and loans (Loans).

Third, we discriminate among the proportion of Level 1, Level 2 (L2) and Level 3 (L3) on total fair value.

$D I S_{\text {levels }}$ is an indicator (dummy) variable taking the value of 1 after 2006. Starting from the first quarter 2007 banks should report to the Federal Reserve Bank of Chicago the break-down of assets and liabilities classified as level 2 and 3. It must be pointed out that SFAS 157 required the disclosure of the level of fair value starting in 2008 , but some firms provided such information in notes to their financial statements as early as 2007 . 
To pursue the analysis, we substitute $D I S_{\text {levels }}$ with the proportion of assets and liabilities classified in each level (L2 and L3). As a consequence, in the same model we consider the total amount of fair value as well as the amount for each level to capture the effect of the methods used to calculate fair values.

Fair value as a measurement basis can be either recurring or non recurring $\left(F V_{\text {non-recurring }}\right) . F V_{\text {non- }}$ recurring measures the assets valued at fair value as a consequence of an impairment test.

\section{Control Variables}

Model (1) includes several control variables. We control for a bank's financial strength by including its level of Tier 1 capital (Tier 1) and for bank type using a dummy variably that is equal to 1 if the bank is a financial holding company and 0 if it is a bank holding company (Financial). We also control for a bank's size (Size) using the natural logarithm of total assets (Barron et al. 2008) and bank's performance using the return on equity ratio $(R O E)$. To control for earnings surprises, we include $\Delta$ Earnings, which is measured as the earnings at time $\mathrm{t}$ minus earning at time $\mathrm{t}-1$ over earning at time t-1. Barth et al. (1998) suggest that the effort, and probably the quality, of analysts' forecasts change according to the amount of tangible assets. In the same vein, Barron et al. (2002a) find that the analyst consensus is negatively affected by the amount of intangible assets. Hence, we include the market to book value $(M B)$ as control for banks' growth opportunities and yearly stock volatility (Volatility). We control also for the number of analyst following (Follow).

Finally we include a four quarter dummy. The dummies capture if an observation belong to the fourth quarter $(2007,2008,2009)$. Table 1 provides a complete list of all variable.

\section{PLEASE INSERT HERE TABLE 1}

\section{EMPIRICAL RESULTS}




\section{Descriptive statistics}

Table 2 provides descriptive information about our research and control variables. Panel A refer to the period from 1996 to 2009 while Panel B is focus on a sub sample of 131 banks from 2008 to 2009. On average, assets and liabilities valued at fair value represent $22.3 \%$ of all assets, with assets liabilities valued at fair value representing the majority (20.7\%). In addition, available for sale assets represent the main component of fair value assets and liabilities at fair value (18.2\%) while held for trading and loans correspond, on average, to $1 \%$ of total assets.

The majority of fair value assets and liabilities are evaluated on the basis of market inputs (level 2). Untabulated statistics reveal that level 2 assets and liabilities are on average $\$ 35.60$ per share, while level 1 are ten times less and level 3 assets and liabilities only \$1.97 per share. Untabulated results show that level 2 assets and liabilities exceed 19\% of all assets while level 1 assets and liabilities are $1.9 \%$ of all assets. Moreover, the average amount of level 3 assets and liabilities represents around $0.9 \%$ of all assets and almost $40 \%$ of banks do not have level 3 assets or liabilities.

Although assets valued on a non-recurring basis represent, on average, only $0.8 \%$ of total assets they are, at least once, more than $1 \%$ for 67 banks. When write-downs do happen, they generate a mean loss equal to $0.2 \%$ of the total assets. Untabulated descriptive statistics show that only a few firms have assets and liabilities measured at Level 1 on a non recurring basis while Level 2 and 3 on a non recurring basis are not so diffuse among companies and their values are $\$ 0.54$ and $\$ 1.47$ per share respectively.

\section{PLEASE INSERT HERE TABLE 2}


As shown in table 2 the average market to book ratio is 1,95 for the entire sample and 1.17 for the panel B. Also the mean value of earnings change is different from the two panels $28.8 \%$ and $55.6 \%$. Moreover, the number of active analyst is more 7 with a median of 5 .

\section{Univariate analysis}

Table 3 presents the results of Spearman cross-correlation. Accuracy (Acc) is negatively correlated with dispersion (Disp) as well as with the precision of common information $(h)$. Moreover, accuracy $(A c c)$ is positively correlated with the precision of idiosyncratic information $(s)$ and negatively with the benefit of aggregating private information $(\rho)$, as well as the across analyst correlation in forecasts error $(U-S E)$. As expected, the precision of common and idiosyncratic information are negatively correlated with each other. Consistent with the BKLS model, the measure of consensus $(\rho)$ is positively linked with $h$ and negatively correlated with $s$, the precision of common and private information respectively. Moreover both the precision of common and idiosyncratic information exhibit a significant correlation with the measures of consensus $(\rho)$ and the benefits of aggregating analyst forecasts, although $h$ and $s$ have opposite signs. In addition, more analyst following is negatively correlated with both precision of common and private information and strongly positively correlated with the benefit of aggregating information. Overall fair value assets and liabilities is positively correlated with accuracy and negatively correlated with dispersion. In line with this evidence are the results about assets at fair value and available for sales. It is worth noticing that the sign of the correlation between held for trading assets and liabilities and information environment variables is the opposite of the sign of the correlation between available for sales and information environment variables.

Untabulated results show that the proportion of level 3 assets and liabilities are strongly positively correlated with dispersion and negatively correlated with both the precision of common and private information. In addition, the amount of assets and liabilities measured at fair value on a non 
recurring basis is negatively correlated with the accuracy (Acc), the precision of common information $(h)$, the precision of idiosyncratic information $(s)$.

\section{Multivariate analyses}

The multivariate analysis consists of three steps. First, we test the impact of fair values and its break down on information environment variables. Second, we focus the requirement of disclosing fair value levels introduced by SFAS 157. Third, we investigated the impact of assets assessed at fair value on a non-recurring basis on information environment. Table 4, 5, 6 and 7 refers to the first step, while tables 8 and 9 refer to the second step and table 10 to the third step.

Models (1) - (5) of table 4 show the impact of the amount of assets and liabilities valued at fair and the break down on the natural logarithm of analyst following. In particular, total fair value (FV), assets at fair value, available for sales and held for trading are significantly negatively associated with analyst following. While, the proportion of liabilities is marginally positively associated with analyst following.

\section{INSERT HERE TABLE 4}

Conversing from the univariate analysis, table 5 underlines that, controlling for several factors, FV has strong significant positive association with dispersion (2) mainly due to a decrease in the precision of common information (3). Therefore, the benefit of aggregating forecast increase when the proportion of fair value assets and liabilities increases.

\section{INSERT HERE TABLE 5}


In line with results presented in table 5 , table 4 presents that when total fair value (FV) is divided in assets and liabilities, the proportion of assets at fair value on total assets has strong significant positive association with dispersion (2) mainly due to a decrease in the precision of common information (3) and marginally due to a reduction of the precision of private information (4). Therefore, the benefit of aggregating forecast increase when the proportion of fair value assets and liabilities increases. In addition, the proportion of liabilities at fair value on total assets is positively associated with dispersion but it is not clear if this effect is due to less precision of common or private information.

\section{INSERT HERE TABLE 6}

Table 7 shows that the association between fair value and information environment variables is related to the categories (available for sales, held for trading and loans). In particular, all the three categories are strongly positively associated with dispersion but with statistically different magnitude. Moreover, all the three categories are strongly negatively associated with the precision of common information while only the proportion of held for trading is significantly negatively associated with the precision of private information. It is worth to notice that both the proportion of held for trading and loans are significantly negatively associated with accuracy. In addition, the presence of higher proportion of held for trading and loans increase the benefit of aggregating analysts' forecasts.

\section{INSERT HERE TABLE 7}

Table 8 underlines the disclosure requirement of Federal Reserve Bank of Chicago and SFAS 157. While overall results on the relationship between fair value and information environment are in line with previous evidences, disclosure requirements seems to have a positive effect on information 
environment. In particular, starting from 2007 more fair value assets and liabilities is associated with more accuracy and less dispersion due to higher precision of public information.

\section{INSERT HERE TABLE 8}

Results reported in table 9 seems to support disclosure improve information environment. In particular, the proportion of assets and liabilities assessed at level 2 is significantly positively associated with accuracy and significantly negatively associated with dispersion due to more precise private information. On the contrary, level 3 is significantly negatively associated with dispersion due to a more decrease of public information respect to private information. Therefore, more level 3 suggests to aggregate analysts' forecasts.

\section{INSERT HERE TABLE 9}

Concerning our third step of analysis, table 10 shows that the proportion of assets assessed at fair value on a non-recurring bases is significantly negatively associated with accuracy and positively associated with dispersion. From model (3) and (5) such evidence seems to be due an decrease in the precision of public information. As consequence, there is a significant positive relationship between fair value non-recurring and benefit of aggregating analysts forecast.

As expected the loss in period $t$ due to impairment test has no association with information environment in period $t+1$.

INSERT HERE TABLE 10 


\section{Additional Sensitivity Analyses}

Prior research shows that auditors' reputation provides credibility to the annual reports they audited (Teoh and Wong, 1993). Behn et al. (2007) point out that audit quality affects accuracy and dispersion of analyst forecasts. Therefore Big4, a dummy variable taking the value of 1 if the auditor is one of the Big 4 audit firms or not, is included in model (1). Since we use quarterly data we decided to exclude Big4 as one of our main control variable because it is not clear when auditor changes. Untabulated results show that including Big4 does not change results significantly both if we use only fourth quarter data or if we assume that the auditor is the same for entire year.

Since the period under study in panel B is characterized by very high turbulence due to the financial crisis, we interact use VIX for proxy investor sentiment toward the market, which may affect their assessment of fair value-based assets and liabilities. In particular, VIX is calculated on a daily basis and measures option volatility for the next 30 days. Untabulated results are in line with those reported.

\section{DISCUSSION AND CONCLUSION}

The purpose of the paper is to assess how 1) the extent of a bank's reliance on FVA for its financial reporting and 2) the FVA-related disclosure affect the quality of the information provided to financial markets. Two alternative hypotheses are put forward. The properties of financial analyst forecasts are used as a proxy for information environment. The sample comprises U.S. commercial banks during the period between 1996 and 2009.

Our results show that, overall, the larger the extent of a bank's assets and liabilities reported at fair value, the more dispersed are analysts' earnings forecasts. Moreover, as fair value increases properties of analysts' forecasts deteriorate, showing a decrease in the precision of public or private information. The informational properties of fair value disclosure decrease as we move from level 2 
to mark-to-model data (level 3). Nevertheless, additional analyses suggest that the disclosure of levels has been beneficial to investors as it enhanced private information precision resulting in more accurate and less dispersed analysts' forecasts. Finally, the disclosure about the valuation of assets that are measured at fair value on a non-recurring basis reduces accuracy and public information precision while enhancing dispersion.

With respect to our initial hypotheses, it may be argued the evidence provides a mixed signal. On one hand, consistent with the view that FVA compromises the reliability of financial reporting and induces artificial volatility, it may be inferred that the greater(smaller) the extent of a bank's exposure to FVA reporting, the lower(higher) the quality of information available to financial markets. Furthermore, within FVA assets and liabilities, the less(more) reliable the measurement basis, the lower the quality of information available (i.e., moving from level 1 to level 3). These arguments lead to the notion that as the disclosure related to FV increases the informational environment improves.

On the other hand, consistent with the view that FVA provides financial markets with relevant information that embeds expectations of a firm's future cash flow performance, it can be expected that the greater(smaller) the extent of a bank's exposure to FVA reporting, the higher(lower) the quality of information available to financial markets. Furthermore, within FVA assets and liabilities, the less(more) transparent the measurement basis, the lower (higher) the quality of information.

The study is subject to some limitations. First, financial analysts are but one class of financial information users and their actions and behaviours may not be reflective of decisions by other users such as individual or institutional investors. However, there is extensive empirical research that suggests that financial analysts play an important role in financial markets and that, as such, their 
actions are relevant and potentially representative of market sentiment as a whole. Second, the period under investigation may or may not be appropriate to gauge the informational properties of fair value disclosure. However, SFAS 157 and SFAS 159 were only enacted in 2006 and could be implemented at the earliest in 2007. Moreover, financial reporting is designed only for fair-weather financial and economic conditions: in some sense, the 2007-2009 period constitutes a stress test of the impact of new fair value measurement and disclosure standards on financial markets.

Future research could extend and compare the impact and consequences of fair value measurement and disclosure among U.S. banks with Europe and/or Asian banks. The impact of bank governance on the informational properties of fair value information could also be investigated further. 


\section{REFERENCES}

Ahmed, A., E. Kilic and G. Lobo. 2006. Does Recognition versus Disclosure Matter? Evidence from Value-Relevance of Banks' Recognized and Disclosed Derivative Financial Instruments. The Accounting Review 81(3): 567-588.

Allen, F. and E. Carletti. 2008. Mark-to-market accounting and liquidity pricing. Journal of Accounting and Economics 45: 358-378.

Asquith, P., M. Mikhail and A. Au. 2005. Information content of equity analyst reports. Journal of Financial Economics 75: 245-282.

Bandyopadhyay, S. P., L. Brown and G. Richardson. 1995. Analysts' use of earnings forecasts in predicting stock returns: Forecast horizon effects. International Journal of Forecasting 11: 429-445.

Barron, O. E.; Byard, D.; Yu, Y., 2008. Earnings surprises that motivate analysts to reduce average forecasts error, The Accounting Review, 83 (2): 303 - 325.

Barron, O.E.; D. Byard, C. Kile, E. J. Riedl, 2002, High-technology intangibles and analysts' forecasts, Journal of Acounting Research, 40 (2): 289-312.

Barron, O., D. Byard, and O. Kim. 2002. Changes in analysts' information around earnings announcements. The Accounting Review 77 (4):821-846

Barron, O., O. Kim, S. Lim, and D. Stevens. 1998. Using analysts' forecasts to measure properties of analysts' information environment. The Accounting Review 73 (4): 421-433.

Barth, M. 1994. Fair value accounting: evidence from investment securities and the market valuation of banks. The Accounting Review, 69(1): 1-25.

Barth, M, W Beaver and W Landsman. 1996. Value-relevance of banks' fair value disclosures under SFAS no 107. The Accounting Review 71(3): 513-37.

Barth, M. 2007. Standard-Setting Measurement Issues and the Relevance of Research. Accounting and Business Research, Special Issue: 7-15.

Barth, M. E., W. H. Beaver and W. R. Landsman. 2001a. The relevance of the value relevance literature for accounting standard setting: another view. Journal of Accounting and Economics 31: 77-104.

Barth, M.E., D.P. Cram, K.K. Nelson. 2001b. Accruals and the Prediction of Future Cash Flows. The Accounting Review 76(1), 27-58.

Barth, M.E., Kasznik, R. And McNichols, M. 1998. Analyst Coverage and Intangible Assets. Working paper, Stanford University.

Barth, M. E, Landsman, W. R, Wahlen, J. M.1995. Fair value accounting: Effects on banks' earnings volatility, regulatory capital, and value of contractual cash flows. Journal of Banking \& Finance 19 (3-4): 577-605. 
Barth, M. and D. Taylor. 2010. In defense of fair value: weighing the evidence on earnings management and asset securitizations. Journal of Accounting and Economics 49: 26-33.

Behn, Bruce K., Choi, Jong-Hag and Kang, Tony, Audit Quality and Properties of Analyst Earnings Forecasts. The Accounting Review 83 (2): 327-349.

Benston, G. J. 2008. The Shortcomings of Fair Value Accounting According to SFAS 157. Journal of Accounting and Public Policy 27(2): 101-114

Bernard, V., R. Merton, and K. Palepu (1995). Mark-to-Market Accounting for Banks and Thrifts: Lessons from the Danish Experience. Journal of Accounting Research 33 (Spring): 1-32.

Beuselinck C., Deloof M. and S. Manigart. 2009. Private Equity Involvement and Earnings Quality. Journal of Business, Finance and Accounting 36(5-6): 587-615.

Beyer, A., Cohen, D.A., Lys, T.Z. and Walther, B.R. 2009. The Financial Reporting Environment: Review of the Recent Literature. Massachusetts Institute of Technology.

Blankespoor, Elizabeth, Linsmeier, Thomas J., Petroni, Kathy R. and Shakespeare, Catherine, Bank Leverage and Credit Risk: What do Fair Values Tell Us? (March 5, 2010). Available at SSRN: http://ssrn.com/abstract $=1565653$

Bushman, R., and A. Smith. 2001. Financial Accounting Information and Corporate Governance. Journal of Accounting and Economics 32, no. 1-3: 237-333.

Dechow, P., L. Myers and C.Shakespeare. 2010. Fair value accounting and gains from asset securitizations: A convenient earnings management tool with compensation side-benefits. Journal of Accounting and Economics, 49, 2-25.

Eccher, E, K Ramesh and S Thiagarajan. 1996. Fair value disclosures by bank holding companies. Journal of Accounting and Economics 22: 79-117.

Fiechter, P. 2010. Application of the Fair Value Option under IAS 39: Effects on the Volatility of Bank Earnings. Working paper, University of Zurich.

Fiechter, P. And Z. Novotny-Farkas. 2011. Pricing of Fair Values during the Financial Crisis: International Evidence. Working paper, University of Zurich and Goethe-University Frankfurt.

Financial Accounting Standards Board. 1993. Accounting for Certain Investments in Debt and Equity Securities. Norwalk, CT.

Financial Accounting Standards Board. 2006. Financial Accounting Standard 157 - Fair Value Measurements. Norwalk, CT.

Financial Accounting Standards Board. 2006. Financial Accounting Standard 159 - The Fair Value Option for Financial Assets and Financial Liabilities. Norwalk, CT.

Financial Accounting Standards Board. 2008. Conceptual Framework for Financial Reporting: The Objective of Financial Reporting and Qualitative Characteristics and Constraints of DecisionUseful Financial Reporting Information. Exposure-Draft. Norwalk, CT. 
Financial Accounting Standards Board. 2010. No. 1710-100 Fair Value Measurements and Disclosures (Topic 820) - Improving Disclosures about Fair Value Measurements. Norwalk, CT.

Financial Accounting Standards Board-International Accounting Standards Board. 2010. Conceptual Framework - Joint Project. (www.fasb.org)

Gartenberg, C.M. and G. Serafeim. 2009. Did Fair Valuation Depress Equity Values during the 2008 Financial Crisis. Working paper, Harvard Business School.

Goh, W.B., J. Ng and K. O. Yong. 2009. Market Pricing of Banks' Fair Value Assets Reported under SFAS 157 during the 2008 Economic Crisis. Working Paper. Massachusetts Institute of Technology and Singapore Management University.

$\mathrm{Gu}, \mathrm{Z}$., 2005. Measuring the precision of analysts' private and common information: Generalization and an application. Working Paper Carnegie Mellon University

Hann, R.N., F. Heflin and K.R. Subramanyam. 2007. Fair-value pension accounting. Journal of Accounting and Economics 44, 327-358.

Healy, P., Palepu, K.G., 2001. Information asymmetry, corporate disclosure, and the capital markets: A review of the empirical disclosure literature. Journal of Accounting and Economics 31(1-3), 405-440.

Holthausen, R.W. and R.L. Watts. 2001. The relevance of the value-relevance literature for financial accounting standard setting. Journal of Accounting \& Economics 31 (1-3): 3-75.

International Accounting Standards Board. 2009a. Fair Value Measurement Guidance. Exposure Draft. May. London: UK.

International Accounting Standards Board. 2009b. Financial Instruments: Classification and Measurement. Exposure Draft. July. London: UK.

Khan, U. 2009. Does Fair Value Accounting Contribute to Systemic Risk in the Banking Industry? Working paper. Michael G. Foster School of Business, University of Washington.

Kolev, K. 2008. Do Investors Perceive Marking-to-Model as Marking-as-Myth? Early Evidence from FAS 157 Disclosure. Working paper. Stern School of Business, New York University.

Laux, C. and C. Leuz. 2010. Did Fair Value Accounting Contribute to the Financial Crisis? Journal of Economic Perspectives. Forthcoming.

Laux, C. And C. Leuz. 2009. The Crisis of Fair Value Accounting: Making Sense of the Recent Debate. Accounting, Organizations \& Society. Forthcoming.

Leuz, C., Verrecchia, R., 2000. The Economic Consequences of Increased Disclosure. Journal of Accounting Research 38, supplement, 91-124.

Linsmeie, T.J. 2011. Financial Reporting and Financial Crises: The Case for Measuring Financial Instruments at Fair Value in the Financial Statements. Accounting Horizons. Forthcoming.

Magnan, M. and G. Markarian. 2010. Accounting and the Crisis. Working paper: IE (Madrid). 
Milburn, J. A. 2008. The Relationship between Fair Value, Market Value, and Efficient Markets. Accounting Perspectives 7(4): 293-316.

Mintz, M.L. 2008. Mark to Market's Liability Lag. July 10, CFO.com.

Nelson, K.K. 1996. Fair Value Accounting for Commercial Banks: An Empirical Analysis of SFAS 107. The Accounting Review 71(2),161-182

O'Brien, P. 2009. Changing the Concepts to Justify the Standards," Accounting. Perspectives 8(4), 263-275.

Plantin, G., H. Sapra and H.S. Shin. 2008. Marking-to-market: Panacea or Pandora's Box? Journal of Accounting Research 46: 435-459.

Saft, J. 2008. Hold-to-Maturity is the new Mark-to-Myth. Reuters (www.reuters.com). September 25.

Scott, W.R. 2008. Financial Accounting Theory. Prentice-Hall: Toronto.

Securities and Exchange Commission. 2008. Report and Recommendations Pursuant to Section 133 of the Emergency Economic Stabilization Act of 2008: Study on Mark-To-Market Accounting. Office Of The Chief Accountant, Division of Corporation Finance (http://www.sec.gov/news/studies/2008/marktomarket123008.pdf)

Song, C.J., W.B. Thomas and H. Yi. 2009. Value Relevance of FAS 157 Fair Value Hierarchy Information and the Impact of Corporate Governance Mechanisms. The Accounting Review 85(4), 1375-1410.

Teoh, S. and T. J. Wong. 1993. Perceived auditor quality and the earnings response coefficient. The Accounting Review 68, 346-366.

Watts, Ross. 2003. Conservatism in accounting part I: Explanations and Implications. Accounting Horizons 17(3): 207-221.

Watts, R. and K. Ramanna. 2009. Evidence on the Effects of Unverifiable Fair-Value Accounting. Harvard Business School Working Paper 08-014 (http://ssrn.com/abstract 1012139) 
Table 1: Selected variables definitions

\section{$\underline{\text { Dependent Variables }}$}

\begin{tabular}{|l|l|}
\hline $\ln \boldsymbol{N}$ & natural logarithm of active analysts \\
\hline $\boldsymbol{A c c}$ & accuracy of analyst forecasts (ranked) \\
\hline $\boldsymbol{D} \boldsymbol{i s p}$ & dispersion of analyst forecasts (ranked) \\
\hline $\mathbf{h}$ & precision of public information calculated as in BKLS \\
\hline $\mathbf{S}$ & precision of private information calculated as in BKLS \\
\hline $\boldsymbol{\rho}$ & across analyst correlation in forecast errors \\
\hline $\boldsymbol{U}-\boldsymbol{S E}$ & benefits of aggregating individual analyst' forecasts \\
\hline
\end{tabular}

\section{Fair Value Variables}

\begin{tabular}{|l|l|}
\hline $\boldsymbol{F V}$ & $\begin{array}{l}\text { total value of assets and liabilities measured at fair value on recurring basis divided by the total value } \\
\text { of assets }\end{array}$ \\
\hline $\boldsymbol{F} \boldsymbol{V}_{-} \boldsymbol{A}$ & total value of assets measured at fair value basis divided by the total value of assets \\
\hline $\boldsymbol{F} \boldsymbol{V}_{-} \boldsymbol{L}$ & total value of liabilities measured at fair value basis divided by the total value of assets \\
\hline $\boldsymbol{A f S}$ & total value of available or sales measured at fair value basis divided by the total value of assets \\
\hline $\boldsymbol{H} \boldsymbol{f} \boldsymbol{L}$ & total value of held for trading measured at fair value basis divided by the total value of assets \\
\hline $\boldsymbol{L o a n s}$ & total value of loans measured at fair value basis divided by the total value of assets \\
\hline $\boldsymbol{D I S} \boldsymbol{S}_{\text {levels }}$ & dummy variable taking the value of 1 if after 2006, zero otherwise \\
\hline $\boldsymbol{L 2}$ & proportion of level 2 assets and liabilities on recurring basis \\
\hline $\boldsymbol{L 3}$ & proportion of level 3 assets and liabilities on recurring basis \\
\hline $\boldsymbol{F} \boldsymbol{V}_{\text {non-recurring }}$ & $\begin{array}{l}\text { total value of assets and liabilities measured at fair value on non recurring basis divided by the total } \\
\text { value of assets }\end{array}$ \\
\hline
\end{tabular}

\section{Control Variables}

\begin{tabular}{|l|l|}
\hline Follow & number of analyst following the company \\
\hline Volatility & yearly stock price volatility \\
\hline Size & natural logarithm of total assets \\
\hline Tier1 & tier 1 capital ratio \\
\hline ROE & return on equity index \\
\hline $\boldsymbol{M B}$ & market value of equity over book value of equity \\
\hline $\boldsymbol{\Delta E a r n i n g s}$ & earnings at time t minus earning at time t-1 over earning at time t-1 \\
\hline IV quarter & dummy variable taking the value of 1 if it is the fourth quarter, zero otherwise \\
\hline Financial & dummy variable taking the value of 1 if the bank is a financial holding bank, zero otherwise \\
\hline
\end{tabular}


Table 2 Descriptive statistics PANEL A

\begin{tabular}{lcccccccc}
\hline & count & mean & $\mathrm{sd}$ & $\mathrm{p} 5$ & $\mathrm{p} 25$ & $\mathrm{p} 50$ & $\mathrm{p} 75$ & $\mathrm{p} 95$ \\
\hline Accuracy & 5963 & -.67 & 1.67 & -2.66 & -.601 & -.152 & -.0399 & -.0075 \\
Dispersion & 5963 & .0233 & .106 & .0000189 & .000181 & .000768 & .00399 & .0841 \\
Public (h) & 5963 & 6.39 & 8.95 & 0 & .936 & 2.69 & 8.16 & 25.5 \\
Private (s) & 5963 & 5.36 & 11.7 & .00368 & .0558 & .66 & 4.44 & 28.8 \\
Consensus (p) & 5963 & .859 & .268 & 0 & .874 & .985 & .999 & 1 \\
Benefit (U_SE) & 5963 & .0491 & .0498 & .00707 & .0134 & .0277 & .0632 & .164 \\
FV & 5963 & .223 & .107 & .078 & .148 & .208 & .278 & .427 \\
FV_A & 5963 & .207 & .0971 & .0725 & .138 & .193 & .262 & .386 \\
FV_L & 5963 & .0164 & .0336 & 0 & 0 & .00304 & .0184 & .0729 \\
AfS & 5963 & .182 & .0956 & .0497 & .112 & .17 & .237 & .36 \\
HfT & 5963 & .0066 & .0278 & 0 & 0 & 0 & .000679 & .0309 \\
Loans & 5963 & .0124 & .0314 & 0 & .000379 & .00305 & .0103 & .0495 \\
Follow & 5963 & 7.27 & 4.91 & 3 & 4 & 5 & 9 & 18 \\
Volatility & 5963 & 3.37 & 11.3 & .348 & .761 & 1.26 & 2.28 & 10.8 \\
Size & 5963 & 6.94 & 1.63 & 4.65 & 5.76 & 6.74 & 7.87 & 9.97 \\
Tier1 & 5963 & .11 & .0269 & .0765 & .0939 & .106 & .122 & .157 \\
ROE & 5963 & .0684 & .0754 & -.00308 & .0363 & .0686 & .108 & .163 \\
MB & 5963 & 1.95 & .867 & .72 & 1.41 & 1.87 & 2.35 & 3.4 \\
$\Delta$ Earnings & 5963 & .288 & 12 & -.812 & -.607 & .404 & .77 & 1.2 \\
IV quarter & 5963 & .273 & .446 & 0 & 0 & 0 & 1 & 1 \\
Financial & 5963 & .384 & .486 & 0 & 0 & 0 & 1 & 1 \\
\hline
\end{tabular}

Table 2 Descriptive statistics PANEL B

\begin{tabular}{|c|c|c|c|c|c|c|c|c|}
\hline & count & mean & $\mathrm{sd}$ & p5 & $\mathrm{p} 25$ & $\mathrm{p} 50$ & $\mathrm{p} 75$ & p95 \\
\hline Accuracy & 649 & -1.97 & 3.38 & -12.5 & -1.62 & -.477 & -.12 & -.0123 \\
\hline Dispersion & 649 & .104 & .21 & .00025 & .00391 & .0192 & .081 & .723 \\
\hline Public (h) & 649 & 2.83 & 5.57 & 0 & .38 & 1.09 & 2.52 & 12.3 \\
\hline Private (s) & 649 & 2.85 & 6.92 & .00584 & .0885 & .52 & 2.54 & 13.8 \\
\hline Consensus $(\rho)$ & 649 & .79 & .315 & 0 & .73 & .952 & .994 & 1 \\
\hline Benefit (U_SE) & 649 & .114 & .056 & .0158 & .0626 & .139 & .164 & .164 \\
\hline $\mathrm{FV}$ & 649 & .226 & .402 & .043 & .109 & .151 & .218 & .399 \\
\hline L1 & 649 & .085 & .211 & 0.00 & 0.00 & .007 & .055 & .596 \\
\hline L2 & 649 & .875 & .227 & .122 & .866 & .958 & .994 & 1 \\
\hline L3 & 649 & .0396 & .093 & 0.00 & 0.00 & .00604 & .0389 & .184 \\
\hline $\mathrm{FV}_{\text {non-recurring }}$ & 606 & .00805 & .0106 & 0.00 & 0.00 & .00429 & .0115 & .0295 \\
\hline Loss & 606 & .000666 & .00158 & 0.00 & 0.00 & 0.00 & .000454 & .00434 \\
\hline Follow & 649 & 8.07 & 5.2 & 3 & 4 & 6 & 10 & 20 \\
\hline Volatility & 649 & 10.8 & 20 & .751 & 2.27 & 5.02 & 10.5 & 37.1 \\
\hline Size & 649 & 6.43 & 1.68 & 3.99 & 5.34 & 6.25 & 7.31 & 9.63 \\
\hline Tier1 & 649 & .107 & .0205 & .078 & .0931 & .102 & .119 & .143 \\
\hline ROE & 649 & .0104 & .0976 & -.152 & .00565 & .0264 & .0544 & .101 \\
\hline MB & 649 & 1.17 & .584 & .37 & .74 & 1.08 & 1.5 & 2.25 \\
\hline$\Delta$ Earnings & 649 & -.556 & 6.24 & -2.61 & -.783 & .00815 & .482 & 1.34 \\
\hline IV quarter & 649 & .206 & .405 & 0 & 0 & 0 & 0 & 1 \\
\hline Financial & 649 & .459 & .499 & 0 & 0 & 0 & 1 & 1 \\
\hline
\end{tabular}

See Table 1 for variables definitions 
Table 3 Correlation Matrix Panel A

\begin{tabular}{|c|c|c|c|c|c|c|c|c|c|c|c|c|c|c|c|c|c|c|c|c|c|}
\hline & & $(1)$ & (2) & (3) & (4) & (5) & (6) & (7) & (8) & (9) & (10) & (11) & (12) & (13) & (14) & (15) & (16) & (17) & (18) & (19) & $(20)$ \\
\hline (1) & Acc & 1 & & & & & & & & & & & & & & & & & & & \\
\hline (2) & Disp & $-0.18 * * *$ & 1 & & & & & & & & & & & & & & & & & & \\
\hline (3) & $\mathbf{H}$ & $0.23^{* * *}$ & $-0.20 * * *$ & 1 & & & & & & & & & & & & & & & & & \\
\hline (4) & $\mathbf{S}$ & $0.18 * * *$ & $-0.14 * * *$ & $0.40^{* * * *}$ & 1 & & & & & & & & & & & & & & & & \\
\hline (5) & $\mathbf{P}$ & $-0.18 * * *$ & $-0.13 * * *$ & $0.08^{* * * *}$ & $-0.61 * * *$ & 1 & & & & & & & & & & & & & & & \\
\hline (6) & U-SE & -0.35 *** & $0.49 * * *$ & $-0.51 * * *$ & $-0.30^{* * *}$ & $-0.14 * * *$ & 1 & & & & & & & & & & & & & & \\
\hline (7) & FV & $0.15 * * *$ & $-0.07 * * *$ & -0.01 & 0.02 & -0.03 & -0.01 & 1 & & & & & & & & & & & & & \\
\hline (8) & FV_A & $0.15 * * *$ & $-0.08 * * *$ & 0.00 & 0.02 & -0.03 & $-0.04 * *$ & $0.94 * * *$ & 1 & & & & & & & & & & & & \\
\hline (9) & FV_L & $0.05 * * *$ & 0.01 & -0.02 & -0.01 & -0.02 & $0.08 * * *$ & $0.46^{* * * *}$ & $0.14 * * *$ & 1 & & & & & & & & & & & \\
\hline (10) & AfS & $0.15^{* * *}$ & $-0.09 * * *$ & 0.03 & $0.04 * *$ & $-0.04 * *$ & $-0.10^{* * *}$ & $0.82 * * *$ & $0.91 * * *$ & 0.01 & 1 & & & & & & & & & & \\
\hline (11) & HfT & 0.02 & $0.07^{* * * *}$ & $-0.09 * * *$ & $-0.06 * * *$ & 0.02 & $0.18^{* * * *}$ & $0.33 * * *$ & $0.20 * * *$ & $0.44 * * *$ & $-0.09 * * *$ & 1 & & & & & & & & & \\
\hline (12) & Loans & -0.02 & 0.01 & -0.03 & -0.01 & 0.03 & $0.06 * * *$ & $0.16 * * *$ & $0.15 * * *$ & $0.08 * * *$ & $-0.13^{* * * *}$ & $0.14 * * *$ & 1 & & & & & & & & \\
\hline (13) & Follow & 0.00 & $0.16^{* * * *}$ & $-0.14 * * *$ & $-0.10^{* * *}$ & -0.02 & $0.31^{* * * *}$ & $0.13 * * *$ & 0.03 & $0.32 * * *$ & $-0.08^{* * * *}$ & $0.36 * * *$ & $0.16 * * *$ & 1 & & & & & & & \\
\hline (14) & Volatility & $-0.19 * * *$ & $0.37^{* * * *}$ & $-0.15^{* * * *}$ & $-0.11 * * *$ & 0.01 & $0.33^{* * * *}$ & $-0.12 * * *$ & $-0.11^{* * *}$ & $-0.08 * * *$ & $-0.09 * * *$ & -0.02 & 0.00 & $-0.04 * *$ & 1 & & & & & & \\
\hline (15) & Size & $0.18 * * *$ & $-0.04 * *$ & -0.03 & -0.01 & -0.03 & $0.06 * * *$ & $0.38 * * *$ & $0.26 * * *$ & $0.43 * * *$ & $0.13 * * *$ & $0.47 * * *$ & $0.12 * * *$ & $0.72 * * *$ & $-0.27 * * *$ & 1 & & & & & \\
\hline (16) & Tier1 & $0.04 * *$ & $-0.03 *$ & 0.02 & 0.01 & $-0.04 * *$ & $-0.06^{* * * *}$ & $0.26 * * *$ & $0.36 * * *$ & $-0.19 * * *$ & $0.42 * * *$ & $-0.15^{* * *}$ & $-0.11^{* * * *}$ & $-0.23 * * *$ & -0.02 & $-0.19^{* * *}$ & 1 & & & & \\
\hline (17) & ROE & $0.22 * * *$ & $-0.50 * * *$ & $0.19 * * *$ & $0.14 * * *$ & 0.03 & $-0.35 * * *$ & $0.16^{* * *}$ & $0.14 * * *$ & $0.09 * * *$ & $0.14 * * *$ & 0.01 & -0.01 & 0.02 & $-0.55^{* * * *}$ & $0.27 * * *$ & -0.03 & 1 & & & \\
\hline (18) & MB & $0.31 * * *$ & $-0.30 * * *$ & $0.27 * * *$ & $0.21 * * *$ & -0.03 & $-0.45^{* * *}$ & $0.21 * * *$ & $0.19 * * *$ & $0.14 * * *$ & $0.20 * * *$ & $-0.06 * * *$ & $-0.04 * *$ & $-0.04 * *$ & $-0.35^{* * *}$ & $0.27 * * *$ & $-0.06^{* * * *}$ & $0.52^{* * * *}$ & 1 & & \\
\hline (19) & $\Delta$ Earnings & 0.03 & $-0.03 *$ & 0.00 & 0.00 & 0.01 & -0.02 & $0.07 * * *$ & $0.07 * * *$ & 0.00 & $0.07 * * *$ & 0.00 & 0.03 & 0.00 & 0.00 & 0.02 & 0.02 & 0.00 & 0.03 & 1 & \\
\hline (20) & Q4 & $0.08 * * *$ & $0.06 * * *$ & $0.17 * * *$ & $0.13 * * *$ & $-0.11 * * *$ & $-0.06^{* * * *}$ & -0.02 & -0.01 & -0.03 & 0.00 & 0.00 & -0.02 & 0.02 & $0.04 * *$ & 0.00 & 0.00 & 0.01 & -0.02 & $0.04 * *$ & 1 \\
\hline (21) & Financial & 0.01 & $0.04 * *$ & $-0.04 *$ & 0.00 & -0.02 & $0.11 * * *$ & $0.12 * * *$ & $0.04 * *$ & $0.22 * * *$ & $-0.04 * *$ & $0.19 * * *$ & $0.14 * * *$ & $0.34 * * *$ & $-0.08 * * *$ & $0.35 * * *$ & $-0.18^{* * * *}$ & $0.06 * * * *$ & 0.03 & -0.02 & $0.21^{* * * *}$ \\
\hline
\end{tabular}


Table 3 Correlation Matrix Panel B

\begin{tabular}{|c|c|c|c|c|c|c|c|c|c|c|c|c|c|c|c|c|c|c|c|c|c|}
\hline & & (1) & (2) & (3) & (4) & (5) & (6) & (7) & (8) & (9) & (10) & (11) & (12) & (13) & (14) & (15) & (16) & (17) & (18) & (19) & (20) \\
\hline (1) & Acc & 1 & & & & & & & & & & & & & & & & & & & \\
\hline (2) & Disp & $-0.15^{* * * *}$ & 1 & & & & & & & & & & & & & & & & & & \\
\hline (3) & H & $0.23 * * *$ & $-0.21 * * *$ & 1 & & & & & & & & & & & & & & & & & \\
\hline (4) & $\mathbf{S}$ & $0.22 * * *$ & $-0.16 * * *$ & $0.38 * * *$ & 1 & & & & & & & & & & & & & & & & \\
\hline (5) & $\mathbf{P}$ & $-0.31^{* * *}$ & $-0.09 * *$ & $0.09 * *$ & $-0.49 * * *$ & 1 & & & & & & & & & & & & & & & \\
\hline (6) & U-SE & $-0.20^{* * *}$ & $0.43^{* * * *}$ & $-0.54 * * *$ & $-0.33^{* * *}$ & $-0.17^{* * * *}$ & 1 & & & & & & & & & & & & & & \\
\hline (7) & FV & $0.13^{* * *}$ & -0.04 & -0.04 & 0.01 & $-0.12^{* * *}$ & $0.07 *$ & 1 & & & & & & & & & & & & & \\
\hline (8) & L1 & 0.00 & -0.03 & 0.01 & -0.05 & $0.06^{*}$ & $-0.09 * *$ & -0.02 & 1 & & & & & & & & & & & & \\
\hline (9) & L2 & -0.01 & -0.06 & 0.03 & $0.09 * *$ & -0.04 & -0.01 & 0.02 & $-0.91 * * *$ & 1 & & & & & & & & & & & \\
\hline (10) & L3 & 0.00 & $0.23^{* * * *}$ & $-0.11 * * *$ & $-0.09^{* *}$ & -0.05 & $0.22^{* * * *}$ & 0 & -0.04 & $-0.37^{* * *}$ & 1 & & & & & & & & & & \\
\hline (11) & $\mathbf{F V}_{\text {non-recurring }}$ & $-0.27^{* * *}$ & $0.12^{* * * *}$ & -0.06 & $-0.11^{* * *}$ & $0.14 * * *$ & $0.21^{* * * *}$ & $-0.11 * * *$ & $-0.0948 * *$ & $0.0850^{* *}$ & -0.0093 & 1 & & & & & & & & & \\
\hline (12) & Loss & $-0.19^{* * * *}$ & $0.13^{* * * *}$ & $-0.10^{* * *}$ & $-0.10^{* * *}$ & 0.06 & $0.14^{* * * *}$ & -0.06 & $-0.0903 * *$ & $0.0834 * *$ & -0.0161 & $0.32 * * *$ & & & & & & & & & \\
\hline (13) & Follow & $0.09 * *$ & $0.19^{* * * *}$ & $-0.18 * * *$ & $-0.12^{* * *}$ & $-0.09 * *$ & $0.35^{* * *}$ & $0.18 * * *$ & 0.00 & $-0.07 *$ & $0.16^{* * * *}$ & -0.06 & -0.01 & 1 & & & & & & & \\
\hline (14) & Volatility & $-0.11^{* * *}$ & $0.21 * * *$ & $-0.10 * * *$ & $-0.11 * * *$ & 0.06 & $0.20 * * *$ & $-0.08 * *$ & $-0.09 * *$ & $0.07 *$ & 0.03 & $0.35 * * *$ & $0.32 * * *$ & $-0.11 * * *$ & 1 & & & & & & \\
\hline (15) & Size & $0.23^{* * *}$ & 0.05 & $-0.08 * *$ & -0.04 & $-0.15^{* * * *}$ & $0.19^{* * * *}$ & $0.41^{* * *}$ & -0.01 & -0.01 & 0.05 & $-0.29 * * *$ & $-0.17^{* * *}$ & $0.73^{* * *}$ & $-0.33^{* * *}$ & 1 & & & & & \\
\hline (16) & Tier1 & $0.08 * *$ & $-0.07 *$ & $0.08^{*}$ & $0.08^{* *}$ & $-0.13 * * *$ & $-0.09 * *$ & 0.04 & -0.03 & 0.04 & -0.01 & -0.06 & -0.02 & $-0.24 * * *$ & 0.01 & $-0.19 * * *$ & 1 & & & & \\
\hline (17) & ROE & $0.20^{* * *}$ & $-0.42 * * *$ & $0.15 * * *$ & $0.16^{* * *}$ & -0.06 & $-0.20 * * *$ & $0.08^{* *}$ & -0.02 & 0.05 & $-0.09 * *$ & $-0.24 * * *$ & $-0.24 * * *$ & 0.04 & $-0.42^{* * *}$ & $0.27 * * *$ & 0.04 & 1 & & & \\
\hline (18) & MB & $0.21^{* * *}$ & $-0.21 * * *$ & $0.11 * * *$ & $0.15^{* * *}$ & $-0.14 * * *$ & $-0.20 * * *$ & $0.10^{* * *}$ & $0.08^{*}$ & -0.02 & $-0.13 * * *$ & $-0.28 * * *$ & $-0.24 * * *$ & -0.06 & $-0.35^{* * *}$ & $0.33^{* * *}$ & 0.01 & $0.42 * * *$ & 1 & & \\
\hline (19) & $\Delta$ Earnings & 0.05 & $-0.19 * * *$ & 0.02 & 0.05 & -0.04 & $-0.07 *$ & 0.03 & 0.00 & -0.01 & 0.01 & $-0.10^{* *}$ & $-0.07 *$ & 0.00 & -0.05 & 0.03 & 0.04 & $0.12 * * *$ & 0.05 & 1 & \\
\hline (20) & Q4 & $0.12 * * *$ & 0.03 & $0.25 * * *$ & $0.24 * * *$ & $-0.13^{* * * *}$ & $-0.20^{* * *}$ & -0.02 & -0.01 & -0.01 & 0.05 & 0.00 & 0.00 & 0.00 & -0.02 & 0.05 & $-0.15^{* * *}$ & 0.04 & $0.18^{* * *}$ & 0.03 & 1 \\
\hline (21) & Financial & 0.04 & 0.05 & $-0.11 * * *$ & $-0.07 *$ & -0.03 & $0.17^{* * * *}$ & $0.09 * *$ & 0.05 & $-0.12^{* * * *}$ & $0.17^{* * * *}$ & $-0.16 * * *$ & $-0.10^{* *}$ & $0.37^{* * * *}$ & $-0.13^{* * *}$ & $0.38 * * *$ & $-0.16^{* * * *}$ & $0.11 * * *$ & $0.07 *$ & 0.01 & 0.00 \\
\hline
\end{tabular}


Table 4

Fair Value and Analyst Coverage (Ln Number of Analyst)

\begin{tabular}{|c|c|c|c|c|c|}
\hline & $\begin{array}{l}(1) \\
\ln N\end{array}$ & $\begin{array}{l}(2) \\
\ln N\end{array}$ & $\begin{array}{l}\text { (3) } \\
\ln N\end{array}$ & $\begin{array}{l}\text { (4) } \\
\ln \mathrm{N}\end{array}$ & (5) \\
\hline CONSTANT & $194 * * *$ & $\frac{\ln N}{206 * * *}$ & $\frac{\ln N}{178 * * *}$ & $\frac{\ln N}{385 * * *}$ & $\frac{\ln N}{200 * * *}$ \\
\hline CUNDIARI & $(4.34)$ & $\begin{array}{c}.206 * * * \\
(4.53)\end{array}$ & $\begin{array}{c}.178 * * * \\
(4.02)\end{array}$ & $\begin{array}{c}.385^{* * * *} \\
(3.33)\end{array}$ & $\begin{array}{c}.299 * * * \\
(3.07)\end{array}$ \\
\hline Volatility & .000466 & .000509 & .000545 & .000302 & .000125 \\
\hline Size & $\begin{array}{l}.283 * * * \\
(63.91)\end{array}$ & $\begin{array}{l}.281 * * * \\
(62.05)\end{array}$ & $\begin{array}{l}.287 * * * \\
(63.02)\end{array}$ & $\begin{array}{l}.28 * * * \\
(29.07)\end{array}$ & $.286 * * *$ \\
\hline Tier1 & $\begin{array}{c}-1.19 * * * \\
(-7.18)\end{array}$ & $\begin{array}{c}-1.11 * * * \\
(-6.24)\end{array}$ & $\begin{array}{c}-1.19 * * * \\
(-7.25)\end{array}$ & $\begin{array}{c}.125 \\
(0.20)\end{array}$ & $\begin{array}{l}.405 \\
(0.62)\end{array}$ \\
\hline ROE & $\begin{array}{c}-.125 * * \\
(-2.19)\end{array}$ & $\begin{array}{c}-.125 * * \\
(-2.18)\end{array}$ & $\begin{array}{l}-.129 * * \\
(-2.23)\end{array}$ & $\begin{array}{l}.0059 \\
(0.05)\end{array}$ & $\begin{array}{l}.0754 \\
(0.67)\end{array}$ \\
\hline MB & $\begin{array}{c}-.0915 * * * \\
(-10.86)\end{array}$ & $\begin{array}{c}-.0899 * * * \\
(-10.66)\end{array}$ & $\begin{array}{c}-.0912 * * * \\
(-10.88)\end{array}$ & $\begin{array}{c}-.258 * * * \\
(-13.13)\end{array}$ & $\begin{array}{c}-.268 * * * \\
(-13.30)\end{array}$ \\
\hline$\Delta$ Earnings & $\begin{array}{c}.000118 \\
(0.35)\end{array}$ & $\begin{array}{c}.000123 \\
(0.36)\end{array}$ & $\begin{array}{c}.0000884 \\
(0.25)\end{array}$ & $\begin{array}{l}-.0012 \\
(-0.81)\end{array}$ & $\begin{array}{c}-.000678 \\
(-0.46)\end{array}$ \\
\hline IV quarter & $\begin{array}{c}.0281 * * * \\
(4.89)\end{array}$ & $\begin{array}{c}.0271 * * * \\
(4.67)\end{array}$ & $\begin{array}{c}.0285 * * * \\
(4.88)\end{array}$ & $\begin{array}{l}.0158 \\
(0.92)\end{array}$ & $\begin{array}{l}.0195 \\
(1.10)\end{array}$ \\
\hline Financial & $\begin{array}{c}.0599 * * * \\
(4.31)\end{array}$ & $\begin{array}{c}.0585 * * * \\
(4.21)\end{array}$ & $\begin{array}{c}.0578 * * * \\
(4.29)\end{array}$ & $\begin{array}{c}.084 * * * \\
(3.12)\end{array}$ & $\begin{array}{c}.0979 * * * \\
(3.50)\end{array}$ \\
\hline $\mathrm{FV}$ & $\begin{array}{c}-.134 * * \\
(-2.39)\end{array}$ & & & $\begin{array}{c}-.125 * * * \\
(-4.50)\end{array}$ & $\begin{array}{c}-.137 * * * \\
(-3.52)\end{array}$ \\
\hline FV_A & & $\begin{array}{l}-.2 * * * \\
(-3.30)\end{array}$ & & & \\
\hline FV_L & & $\begin{array}{l}.316^{*} \\
(1.70)\end{array}$ & & & \\
\hline AfS & & & $\begin{array}{c}-.177 * * * \\
(-2.92)\end{array}$ & & \\
\hline HfT & & & $\begin{array}{c}-.822 * * * \\
(-3.46)\end{array}$ & & \\
\hline Loans & & & $\begin{array}{c}.273 \\
(1.48)\end{array}$ & & \\
\hline L2 & & & & $\begin{array}{c}-.00454 \\
(-0.09)\end{array}$ & \\
\hline L3 & & & & $\begin{array}{l}.155 \\
(1.31)\end{array}$ & \\
\hline $\mathrm{FV}_{\text {non-recurring }}$ & & & & & $\begin{array}{c}.091 \\
(0.08)\end{array}$ \\
\hline Loss & & & & & $\begin{array}{l}12.21 * \\
(1.69)\end{array}$ \\
\hline Year & Yes & Yes & Yes & Yes & Yes \\
\hline chi2 & 6075.8 & 6019.6 & 6621.0 & 1248.9 & 1151.9 \\
\hline N. of cases & 5963 & 5963 & 5963 & 649 & 606 \\
\hline N. of banks & 309 & 309 & 309 & 131 & 131 \\
\hline average group size & 19.3 & 19.3 & 19.3 & 4.95 & 4.63 \\
\hline
\end{tabular}

Std. Err. adjusted for clusters $\mathrm{t}$-statistics in parentheses

$* \mathrm{p}<0.10, * * \mathrm{p}<0.05, * * * \mathrm{p}<0.01$

See Table 1 for variables definitions 
Table 5

Fair Value and the Information Properties of Analysts' Forecasts

\begin{tabular}{|c|c|c|c|c|c|c|}
\hline & $\begin{array}{c}(1) \\
\text { accuracy }\end{array}$ & $\begin{array}{c}(2) \\
\text { dispersion }\end{array}$ & $\begin{array}{l}\text { (3) } \\
\mathrm{h}\end{array}$ & $\begin{array}{c}(4) \\
\mathrm{s}\end{array}$ & $\begin{array}{c}(5) \\
\rho\end{array}$ & $\begin{array}{c}(6) \\
\mathrm{U}-\mathrm{SE}\end{array}$ \\
\hline CONSTANT & $\begin{array}{c}25.4 * * * \\
(5.86)\end{array}$ & $\begin{array}{l}7.01 * * \\
(2.21)\end{array}$ & $\begin{array}{c}4.62 * * * \\
(6.29)\end{array}$ & $\begin{array}{c}.924 \\
(1.15)\end{array}$ & $\begin{array}{l}1.03 * * * \\
(52.80)\end{array}$ & $\begin{array}{l}.00461 \\
(1.28)\end{array}$ \\
\hline $\mathrm{FV}$ & $\begin{array}{c}-1.16 \\
(-0.20)\end{array}$ & $\begin{array}{c}30.7 * * * \\
(6.61)\end{array}$ & $\begin{array}{c}-3.64 * * * \\
(-3.83)\end{array}$ & $\begin{array}{c}-1.61 \\
(-1.59)\end{array}$ & $\begin{array}{l}.00646 \\
(0.24)\end{array}$ & $\begin{array}{c}.0201 * * * \\
(3.78)\end{array}$ \\
\hline Follow & $\begin{array}{l}.152 \\
(1.53)\end{array}$ & $\begin{array}{l}1.63 * * * \\
(15.99)\end{array}$ & $\begin{array}{l}-.0285 \\
(-1.24)\end{array}$ & $\begin{array}{l}-.0235 \\
(-1.01)\end{array}$ & $\begin{array}{c}.0000221 \\
(0.03)\end{array}$ & $\begin{array}{c}.00151 * * * \\
(11.62)\end{array}$ \\
\hline Volatility & $\begin{array}{c}-.189 * * * \\
(-3.87)\end{array}$ & $\begin{array}{c}.197 * * * \\
(3.77)\end{array}$ & $\begin{array}{c}-.0186 * * \\
(-2.21)\end{array}$ & $\begin{array}{l}-.0101 \\
(-1.19)\end{array}$ & $\begin{array}{c}.000309 \\
(1.22)\end{array}$ & $\begin{array}{c}.000335 * * * \\
(6.36)\end{array}$ \\
\hline Size & $\begin{array}{c}2.87 * * * \\
(5.36)\end{array}$ & $\begin{array}{l}3.5 * * * \\
(8.26)\end{array}$ & $\begin{array}{c}-.204 * * \\
(-2.31)\end{array}$ & $\begin{array}{l}.0774 \\
(0.84)\end{array}$ & $\begin{array}{c}-.0104 * * * \\
(-4.03)\end{array}$ & $\begin{array}{c}.00274 * * * \\
(5.65)\end{array}$ \\
\hline Tier1 & $\begin{array}{c}-59.7 * * * \\
(-3.47)\end{array}$ & $\begin{array}{c}-9.19 \\
(-1.36)\end{array}$ & $\begin{array}{c}-8.39 * * * \\
(-2.87)\end{array}$ & $\begin{array}{c}-4.84 \\
(-1.26)\end{array}$ & $\begin{array}{c}.138 \\
(1.49)\end{array}$ & $\begin{array}{l}-.0221 \\
(-1.55)\end{array}$ \\
\hline ROE & $\begin{array}{l}-41 * * * \\
(-8.69)\end{array}$ & $\begin{array}{c}-44.6 * * * \\
(-7.45)\end{array}$ & $\begin{array}{c}-1.34 \\
(-1.14)\end{array}$ & $\begin{array}{c}-1.68 \\
(-1.55)\end{array}$ & $\begin{array}{c}.139 * * * \\
(3.95)\end{array}$ & $\begin{array}{c}.00558 \\
(0.95)\end{array}$ \\
\hline MB & $\begin{array}{c}-.639 \\
(-0.92)\end{array}$ & $\begin{array}{l}-6.85 * * * \\
(-11.00)\end{array}$ & $\begin{array}{c}.401 * * * \\
(2.92)\end{array}$ & $\begin{array}{c}.157 \\
(1.09)\end{array}$ & $\begin{array}{c}-.00157 \\
(-0.39)\end{array}$ & $\begin{array}{c}-.00477 * * * \\
(-7.07)\end{array}$ \\
\hline$\Delta$ Earnings & $\begin{array}{c}-.0527 * * * \\
(-3.06)\end{array}$ & $\begin{array}{c}.0539 * * * \\
(2.71)\end{array}$ & $\begin{array}{c}-.00586 * \\
(-1.71)\end{array}$ & $\begin{array}{c}-.00362 \\
(-1.16)\end{array}$ & $\begin{array}{c}.0000546 \\
(0.36)\end{array}$ & $\begin{array}{l}9.04 \mathrm{e}-06 \\
(0.29)\end{array}$ \\
\hline IV quarter & $\begin{array}{l}5.25 * * * \\
(12.18)\end{array}$ & $\begin{array}{c}4.43 * * * \\
(7.66)\end{array}$ & $\begin{array}{l}1.5 * * * \\
(13.39)\end{array}$ & $\begin{array}{c}.871 * * * \\
(7.98)\end{array}$ & $\begin{array}{c}-.0161 * * * \\
(-4.63)\end{array}$ & $\begin{array}{c}-.00733 * * * \\
(-13.22)\end{array}$ \\
\hline $\begin{array}{l}\text { Financial } \\
\text { Year }\end{array}$ & $\begin{array}{c}-.912 \\
(-0.58) \\
\text { Yes }\end{array}$ & $\begin{array}{c}5.69 * * * \\
(4.56) \\
\text { Yes }\end{array}$ & $\begin{array}{c}-.177 \\
(-0.70) \\
\text { Yes }\end{array}$ & $\begin{array}{c}.105 \\
(0.39) \\
\text { Yes }\end{array}$ & $\begin{array}{c}-.0178 * * * \\
(-2.61) \\
\text { Yes }\end{array}$ & $\begin{array}{c}.00231 * \\
(1.92) \\
\text { Yes }\end{array}$ \\
\hline chi2 & 667.8 & 2873.5 & 604.7 & 246.5 & 308.5 & 4217.5 \\
\hline N. of cases & 5963 & 5963 & 5963 & 5963 & 5963 & 5963 \\
\hline N. of banks & 309 & 309 & 309 & 309 & 309 & 309 \\
\hline average group size & 19.3 & 19.3 & 19.3 & 19.3 & 19.3 & 19.3 \\
\hline
\end{tabular}

Std. Err. adjusted for clusters

t-statistics in parentheses

$* \mathrm{p}<0.10, * * \mathrm{p}<0.05, * * * \mathrm{p}<0.01$

See Table 1 for variables definitions 
Table 6

Fair Value Assets and Liabilities and the Information Properties of Analysts' Forecasts

\begin{tabular}{|c|c|c|c|c|c|c|}
\hline & $\begin{array}{c}(1) \\
\text { accuracy }\end{array}$ & $\begin{array}{c}(2) \\
\text { dispersion }\end{array}$ & $\begin{array}{l}\text { (3) } \\
\text { h }\end{array}$ & $\begin{array}{l}\text { (4) } \\
\mathrm{s}\end{array}$ & $\begin{array}{l}(5) \\
\rho\end{array}$ & $\begin{array}{c}(6) \\
\text { U-SE }\end{array}$ \\
\hline \multirow[t]{2}{*}{ CONSTANT } & $27.4 * * *$ & $8.39 * *$ & $4.73 * * *$ & 1.04 & $1.03^{* * * *}$ & .00542 \\
\hline & $(6.24)$ & $(2.48)$ & $(6.30)$ & $(1.28)$ & $(52.23)$ & $(1.50)$ \\
\hline \multirow[t]{2}{*}{ FV_A } & -8.03 & $27.3^{* * *}$ & $-4.02 * * *$ & $-2.08 *$ & 0182 & $.017 * * *$ \\
\hline & $(-1.23)$ & $(4.98)$ & $(-3.73)$ & $(-1.86)$ & $(0.63)$ & (2.99) \\
\hline \multirow{2}{*}{ FV_L } & $31.3 *$ & $44.3 * * *$ & -1.76 & 1.69 & -.122 & $.0387 * *$ \\
\hline & (1.96) & $(3.58)$ & $(-0.64)$ & $(0.49)$ & $(-1.15)$ & $(2.57)$ \\
\hline \multirow[t]{2}{*}{ Follow } & .145 & $1.63^{* * *}$ & -.0292 & -.0244 & .0000862 & $.0015 * * *$ \\
\hline & $(1.46)$ & (15.95) & $(-1.27)$ & $(-1.04)$ & $(0.11)$ & (11.54) \\
\hline \multirow[t]{2}{*}{ Volatility } & $-.191 * * *$ & $.195 * * *$ & $-.0187 * *$ & -.0103 & .000318 & $.000335 * * *$ \\
\hline & $(-3.90)$ & $(3.73)$ & $(-2.22)$ & $(-1.22)$ & $(1.25)$ & $(6.37)$ \\
\hline \multirow[t]{2}{*}{ Size } & $2.71 * * *$ & $3.4 * * *$ & $-.217 * *$ & .0564 & $-.00977 * * *$ & $.00267 * * *$ \\
\hline & $(5.02)$ & (7.83) & $(-2.40)$ & $(0.60)$ & $(-3.74)$ & $(5.48)$ \\
\hline \multirow[t]{2}{*}{ Tier1 } & $-57.9 * * *$ & -9.93 & $-8.11 * * *$ & -4.29 & .123 & -.0194 \\
\hline & $(-3.56)$ & $(-1.33)$ & $(-2.73)$ & $(-1.11)$ & $(1.32)$ & $(-1.46)$ \\
\hline \multirow[t]{2}{*}{ ROE } & $-41 * * *$ & $-44.6 * * *$ & -1.31 & -1.66 & $.138 * * *$ & .00557 \\
\hline & $(-8.74)$ & $(-7.44)$ & $(-1.12)$ & $(-1.53)$ & $(3.92)$ & $(0.95)$ \\
\hline \multirow[t]{2}{*}{ MB } & -.591 & $-6.77 * * *$ & $.409 * * *$ & .177 & -.00204 & $-.00477 * * *$ \\
\hline & $(-0.86)$ & $(-10.80)$ & $(2.96)$ & $(1.22)$ & $(-0.50)$ & $(-7.06)$ \\
\hline \multirow[t]{2}{*}{$\Delta$ Earnings } & $-.0523 * * *$ & $.0541 * * *$ & $-.00582 *$ & -.00356 & .0000543 & $9.41 \mathrm{e}-06$ \\
\hline & $(-3.05)$ & $(2.72)$ & $(-1.70)$ & $(-1.14)$ & $(0.36)$ & $(0.30)$ \\
\hline \multirow[t]{2}{*}{ IV quarter } & $5.24 * * *$ & $4.41 * * *$ & $1.5^{* * *}$ & $.867 * * *$ & $-.0159 * * *$ & $-.00737 * * *$ \\
\hline & (12.37) & (7.59) & (13.36) & (7.94) & $(-4.58)$ & $(-13.27)$ \\
\hline \multirow[t]{2}{*}{ Financial } & -1.02 & $5.62 * * *$ & -.186 & .0951 & $-.0177 * * *$ & $.00217^{*}$ \\
\hline & $(-0.65)$ & $(4.48)$ & $(-0.74)$ & $(0.35)$ & $(-2.59)$ & $(1.81)$ \\
\hline Year & Yes & Yes & Yes & Yes & Yes & Yes \\
\hline chi2 & 681.9 & 2670.7 & 604.6 & 247.3 & 310.5 & 4241.3 \\
\hline N. of cases & 5963 & 5963 & 5963 & 5963 & 5963 & 5963 \\
\hline N. of banks & 309 & 309 & 309 & 309 & 309 & 309 \\
\hline average group size & 19.3 & 19.3 & 19.3 & 19.3 & 19.3 & 19.3 \\
\hline
\end{tabular}

Std. Err. adjusted for clusters

$\mathrm{t}$-statistics in parentheses

$* \mathrm{p}<0.10, * * \mathrm{p}<0.05, * * * \mathrm{p}<0.01$

See Table 1 for variables definitions 
Table 7

Fair Value Asset Categories and Information Properties of Analysts' Forecasts

\begin{tabular}{|c|c|c|c|c|c|c|}
\hline & $\begin{array}{c}(1) \\
\text { accuracy }\end{array}$ & $\begin{array}{c}(2) \\
\text { dispersion }\end{array}$ & $\begin{array}{l}\text { (3) } \\
\mathrm{h}\end{array}$ & $\begin{array}{c}(4) \\
\mathrm{S}\end{array}$ & $\begin{array}{l}(5) \\
\rho\end{array}$ & $\begin{array}{c}(6) \\
\text { U-SE }\end{array}$ \\
\hline CONSTANT & $\begin{array}{c}20.6^{* * * *} \\
(4.94)\end{array}$ & $\begin{array}{l}8.2 * * \\
(2.28)\end{array}$ & $\begin{array}{c}4.15 * * * \\
(5.65)\end{array}$ & $\begin{array}{c}.586 \\
(0.73)\end{array}$ & $\begin{array}{l}1.04 * * * \\
(54.72)\end{array}$ & $\begin{array}{c}.00807 * * \\
(2.26)\end{array}$ \\
\hline AfS & $\begin{array}{c}2.22 \\
(0.32)\end{array}$ & $\begin{array}{c}20.6^{* * * *} \\
(3.46)\end{array}$ & $\begin{array}{l}-2.62 * * \\
(-2.33)\end{array}$ & $\begin{array}{l}-.948 \\
(-0.81)\end{array}$ & $\begin{array}{l}-.00158 \\
(-0.05)\end{array}$ & $\begin{array}{l}.00689 \\
(1.17)\end{array}$ \\
\hline HfT & $\begin{array}{c}-95.9 * * * \\
(-3.99)\end{array}$ & $\begin{array}{c}48.9^{* * * *} \\
(3.84)\end{array}$ & $\begin{array}{l}-11 * * * * \\
(-4.41)\end{array}$ & $\begin{array}{c}-8.82 * * * \\
(-3.03)\end{array}$ & $\begin{array}{l}.219 * \\
(1.78)\end{array}$ & $\begin{array}{c}.209 * * * \\
(7.35)\end{array}$ \\
\hline Loans & $\begin{array}{c}-36.5 * * * \\
(-3.38)\end{array}$ & $\begin{array}{c}62.2 * * * \\
(3.91)\end{array}$ & $\begin{array}{l}-7.34 * * \\
(-2.47)\end{array}$ & $\begin{array}{l}-4.16 \\
(-1.55)\end{array}$ & $\begin{array}{l}.0904 \\
(1.33)\end{array}$ & $\begin{array}{l}.0302 * \\
(1.80)\end{array}$ \\
\hline Follow & $\begin{array}{c}.161 \\
(1.62)\end{array}$ & $\begin{array}{l}1.61 * * * \\
(15.66)\end{array}$ & $\begin{array}{l}-.0318 \\
(-1.39)\end{array}$ & $\begin{array}{l}-.0229 \\
(-0.98)\end{array}$ & $\begin{array}{c}-.0000918 \\
(-0.12)\end{array}$ & $\begin{array}{c}.00143 * * * \\
(11.07)\end{array}$ \\
\hline Volatility & $\begin{array}{c}-.181 * * * \\
(-3.72)\end{array}$ & $\begin{array}{c}.189 * * * \\
(3.57)\end{array}$ & $\begin{array}{c}-.0181 * * \\
(-2.15)\end{array}$ & $\begin{array}{c}-.00925 \\
(-1.11)\end{array}$ & $\begin{array}{c}.000271 \\
(1.08)\end{array}$ & $\begin{array}{c}.00032 * * * \\
(6.09)\end{array}$ \\
\hline Size & $\begin{array}{c}3.83 * * * \\
(7.35)\end{array}$ & $\begin{array}{c}3.47 * * * \\
(7.60)\end{array}$ & $\begin{array}{l}-.107 \\
(-1.14)\end{array}$ & $\begin{array}{l}.163^{*} \\
(1.70)\end{array}$ & $\begin{array}{c}-.0118 * * * \\
(-4.51)\end{array}$ & $\begin{array}{c}.00206 * * * \\
(4.13)\end{array}$ \\
\hline Tier1 & $\begin{array}{c}-59.5 * * * \\
(-3.29)\end{array}$ & $\begin{array}{l}-9.16 \\
(-0.78)\end{array}$ & $\begin{array}{c}-9.53 * * * \\
(-3.49)\end{array}$ & $\begin{array}{c}-5.99 \\
(-1.57)\end{array}$ & $\begin{array}{l}.139 \\
(1.59)\end{array}$ & $\begin{array}{c}-.00764 \\
(-0.62)\end{array}$ \\
\hline ROE & $\begin{array}{c}-41.2 * * * \\
(-8.87)\end{array}$ & $\begin{array}{c}-44.6^{* * * *} \\
(-7.47)\end{array}$ & $\begin{array}{l}-1.23 \\
(-1.05)\end{array}$ & $\begin{array}{l}-1.51 \\
(-1.41)\end{array}$ & $\begin{array}{l}.13 * * * \\
(3.75)\end{array}$ & $\begin{array}{c}.006 \\
(1.04)\end{array}$ \\
\hline MB & $\begin{array}{l}-1.14^{*} \\
(-1.66)\end{array}$ & $\begin{array}{c}-6.67 * * * \\
(-10.19)\end{array}$ & $\begin{array}{l}.335^{* * *} \\
(2.38)\end{array}$ & $\begin{array}{c}.106 \\
(0.72)\end{array}$ & $\begin{array}{c}-.000767 \\
(-0.19)\end{array}$ & $\begin{array}{c}-.0041 * * * \\
(-6.05)\end{array}$ \\
\hline$\Delta$ Earnings & $\begin{array}{c}-.0538 * * * \\
(-3.16)\end{array}$ & $\begin{array}{c}.0524 * * * \\
(2.63)\end{array}$ & $\begin{array}{l}-.00558 \\
(-1.61)\end{array}$ & $\begin{array}{c}-.00346 \\
(-1.10)\end{array}$ & $\begin{array}{c}.0000534 \\
(0.36)\end{array}$ & $\begin{array}{c}8.65 \mathrm{e}-06 \\
(0.28)\end{array}$ \\
\hline IV quarter & $\begin{array}{l}5.13 * * * \\
(11.78)\end{array}$ & $\begin{array}{c}4.51 * * * \\
(7.67)\end{array}$ & $\begin{array}{c}1.49 * * * \\
(13.28)\end{array}$ & $\begin{array}{c}.858 * * * \\
(7.92)\end{array}$ & $\begin{array}{c}-.0157 * * * \\
(-4.59)\end{array}$ & $\begin{array}{c}-.00735^{* * * *} \\
(-13.39)\end{array}$ \\
\hline Financial & $\begin{array}{c}-.969 \\
(-0.62)\end{array}$ & $\begin{array}{c}5.84 * * * \\
(4.58)\end{array}$ & $\begin{array}{l}-.208 \\
(-0.84)\end{array}$ & $\begin{array}{l}.0743 \\
(0.27)\end{array}$ & $\begin{array}{c}-.0185 * * * \\
(-2.74)\end{array}$ & $\begin{array}{l}.00198 \\
(1.63)\end{array}$ \\
\hline Year & Yes & Yes & Yes & Yes & Yes & Yes \\
\hline chi2 & 843.6 & 2400.8 & 629.2 & 252.6 & 318.9 & 4190.1 \\
\hline N. of cases & 5963 & 5963 & 5963 & 5963 & 5963 & 5963 \\
\hline N. of banks & 309 & 309 & 309 & 309 & 309 & 309 \\
\hline average group size & 19.3 & 19.3 & 19.3 & 19.3 & 19.3 & 19.3 \\
\hline
\end{tabular}

Std. Err. adjusted for clusters

$\mathrm{t}$-statistics in parentheses

No change without fv_tot

$* \mathrm{p}<0.10, * * \mathrm{p}<0.05, * * * \mathrm{p}<0.01$

See Table 1 for variables definitions 
Table 8

Fair Value, Disclosure Regime and Information Properties of Analysts' Forecasts

\begin{tabular}{|c|c|c|c|c|c|c|}
\hline & $\begin{array}{c}(1) \\
\text { accuracy }\end{array}$ & $\begin{array}{c}(2) \\
\text { dispersion }\end{array}$ & $\begin{array}{l}\text { (3) } \\
\mathrm{h}\end{array}$ & $\begin{array}{c}(4) \\
\mathrm{s}\end{array}$ & $\begin{array}{l}(5) \\
\rho\end{array}$ & $\begin{array}{c}(6) \\
\text { U-SE }\end{array}$ \\
\hline CONSTANT & $\begin{array}{c}65.9 * * * \\
(8.92)\end{array}$ & $\begin{array}{c}49.4 * * * \\
(7.62)\end{array}$ & $\begin{array}{c}10.6 * * * \\
(9.72)\end{array}$ & $\begin{array}{c}4.84 * * * * \\
(3.39)\end{array}$ & $\begin{array}{l}1.06 * * * \\
(27.02)\end{array}$ & $\begin{array}{l}.0097 \\
(1.53)\end{array}$ \\
\hline FV & $\begin{array}{c}-37.7 * * * \\
(-3.18)\end{array}$ & $\begin{array}{l}39 * * * \\
(3.98)\end{array}$ & $\begin{array}{l}-5.9 * * * \\
(-3.62)\end{array}$ & $\begin{array}{l}-3.12 \\
(-1.44)\end{array}$ & $\begin{array}{l}.0624 \\
(0.99)\end{array}$ & $\begin{array}{l}.0173^{*} \\
(1.73)\end{array}$ \\
\hline DIS $_{\text {Levels }}$ & $\begin{array}{c}-20.2 * * * \\
(-4.46)\end{array}$ & $\begin{array}{c}-17.7 * * * \\
(-4.48)\end{array}$ & $\begin{array}{c}-6.18 * * * \\
(-9.33)\end{array}$ & $\begin{array}{l}-4 * * * \\
(-4.70)\end{array}$ & $\begin{array}{l}-.0422 \\
(-1.60)\end{array}$ & $\begin{array}{c}.0867 * * * \\
(20.84)\end{array}$ \\
\hline $\mathrm{FV}^{*} \mathrm{DIS}_{\text {Levels }}$ & $\begin{array}{c}72.4 * * * \\
(4.72)\end{array}$ & $\begin{array}{c}-27.3 * * \\
(-2.14)\end{array}$ & $\begin{array}{c}6.75 * * * \\
(3.26)\end{array}$ & $\begin{array}{c}2.64 \\
(0.95)\end{array}$ & $\begin{array}{l}-.0784 \\
(-0.88)\end{array}$ & $\begin{array}{l}.00611 \\
(0.43)\end{array}$ \\
\hline Follow & $\begin{array}{c}-.289 \\
(-1.29)\end{array}$ & $\begin{array}{c}2.35^{* * *} \\
(11.96)\end{array}$ & $\begin{array}{l}-.0315 \\
(-0.93)\end{array}$ & $\begin{array}{c}-.032 \\
(-0.76)\end{array}$ & $\begin{array}{c}-.000246 \\
(-0.17)\end{array}$ & $\begin{array}{c}.00187 * * * \\
(8.49)\end{array}$ \\
\hline Volatility & $\begin{array}{c}-.133^{* *} \\
(-2.48)\end{array}$ & $\begin{array}{c}.209 * * * * \\
(3.88)\end{array}$ & $\begin{array}{c}-.0166^{* *} \\
(-2.04)\end{array}$ & $\begin{array}{l}-.0122 \\
(-1.27)\end{array}$ & $\begin{array}{c}.000367 \\
(1.34)\end{array}$ & $\begin{array}{c}.000321 * * * \\
(5.48)\end{array}$ \\
\hline Size & $\begin{array}{c}3.62 * * * \\
(3.83)\end{array}$ & $\begin{array}{c}3.07 * * * \\
(4.07)\end{array}$ & $\begin{array}{c}-.348 * * * \\
(-2.84)\end{array}$ & $\begin{array}{l}-.0691 \\
(-0.44)\end{array}$ & $\begin{array}{c}-.0139 * * * \\
(-2.73)\end{array}$ & $\begin{array}{c}.00259 * * * \\
(3.06)\end{array}$ \\
\hline Tier1 & $\begin{array}{l}-62.9^{*} \\
(-1.66)\end{array}$ & $\begin{array}{c}-72.1 * * \\
(-2.12)\end{array}$ & $\begin{array}{c}-5.84 \\
(-1.03)\end{array}$ & $\begin{array}{c}6.61 \\
(0.87)\end{array}$ & $\begin{array}{c}-.428 * * \\
(-2.05)\end{array}$ & $\begin{array}{l}-.0559^{*} \\
(-1.68)\end{array}$ \\
\hline ROE & $\begin{array}{c}-32.3 * * * \\
(-4.25)\end{array}$ & $\begin{array}{c}-51.2 * * * \\
(-6.01)\end{array}$ & $\begin{array}{c}.357 \\
(0.24)\end{array}$ & $\begin{array}{c}-.372 \\
(-0.24)\end{array}$ & $\begin{array}{c}.207^{* * *} \\
(4.06)\end{array}$ & $\begin{array}{c}-.00182 \\
(-0.22)\end{array}$ \\
\hline MB & $\begin{array}{c}1.78 \\
(1.27)\end{array}$ & $\begin{array}{c}-7.81 * * * \\
(-6.26)\end{array}$ & $\begin{array}{l}.575^{* *} \\
(2.56)\end{array}$ & $\begin{array}{c}.452 \\
(1.60)\end{array}$ & $\begin{array}{c}-.0217 * * * \\
(-2.63)\end{array}$ & $\begin{array}{c}-.0039 * * * \\
(-3.08)\end{array}$ \\
\hline$\Delta$ Earnings & $\begin{array}{c}-.0544 * * \\
(-2.06)\end{array}$ & $\begin{array}{l}.0474 \\
(1.39)\end{array}$ & $\begin{array}{c}-.00721^{*} \\
(-1.74)\end{array}$ & $\begin{array}{c}-.00602 \\
(-1.18)\end{array}$ & $\begin{array}{c}.000331 \\
(1.01)\end{array}$ & $\begin{array}{c}-5.62 \mathrm{e}-06 \\
(-0.12)\end{array}$ \\
\hline IV quarter & $\begin{array}{c}1.14 \\
(1.34)\end{array}$ & $\begin{array}{l}-1.29 \\
(-1.33)\end{array}$ & $\begin{array}{c}2.13 * * * \\
(12.66)\end{array}$ & $\begin{array}{c}1.75 * * * \\
(8.51)\end{array}$ & $\begin{array}{c}-.0566 * * * \\
(-8.10)\end{array}$ & $\begin{array}{c}-.00669 * * * \\
(-7.73)\end{array}$ \\
\hline Financial & $\begin{array}{l}-4.12^{*} \\
(-1.89)\end{array}$ & $\begin{array}{c}8.3 * * * \\
(4.59)\end{array}$ & $\begin{array}{l}-.575^{*} \\
(-1.96)\end{array}$ & $\begin{array}{c}-.164 \\
(-0.43)\end{array}$ & $\begin{array}{c}-.0177^{*} \\
(-1.70)\end{array}$ & $\begin{array}{c}.00454 * * * \\
(2.71)\end{array}$ \\
\hline Year & Yes & Yes & Yes & Yes & Yes & Yes \\
\hline chi2 & 98.9 & 1153.7 & 628.9 & 189.0 & 141.4 & 3154.9 \\
\hline N. of cases & 3284 & 3284 & 3284 & 3284 & 3284 & 3284 \\
\hline N. of banks & 219 & 219 & 219 & 219 & 219 & 219 \\
\hline average group size & 15.0 & 15.0 & 15.0 & 15.0 & 15.0 & 15.0 \\
\hline
\end{tabular}

Std. Err. adjusted for clusters

$\mathrm{t}$-statistics in parentheses

no change with full sample

$* \mathrm{p}<0.10, * * \mathrm{p}<0.05, * * * \mathrm{p}<0.01$

See Table 1 for variables definitions 
Table 9

Fair Value Level Disclosure and Information Properties of Analyts' Forecasts

\begin{tabular}{|c|c|c|c|c|c|c|}
\hline & (1) & (2) & (3) & (4) & (5) & (6) \\
\hline & accuracy & dispersion & $\mathrm{h}$ & $\mathrm{s}$ & $\rho$ & U-SE \\
\hline \multirow[t]{2}{*}{ CONSTANT } & -1.28 & $84.8^{* * * *}$ & $3.02 * * *$ & .605 & $1.12 * * *$ & $.074 * * *$ \\
\hline & $(-0.09)$ & $(7.23)$ & $(2.62)$ & $(0.53)$ & (15.16) & $(4.26)$ \\
\hline \multirow[t]{2}{*}{ FV } & 3.36 & -4.68 & -.135 & $.529 * *$ & $-.0939 * *$ & -.00839 \\
\hline & $(0.78)$ & $(-1.55)$ & $(-0.50)$ & $(2.11)$ & $(-2.01)$ & $(-1.48)$ \\
\hline \multirow[t]{2}{*}{ L2 } & $17.2 * * *$ & $-9.71 *$ & .792 & $1.76 * * *$ & -.0126 & -.00608 \\
\hline & (3.78) & $(-1.84)$ & $(1.55)$ & $(3.51)$ & $(-0.37)$ & $(-0.81)$ \\
\hline \multirow[t]{2}{*}{ L3 } & .526 & $50.8^{* * *}$ & -.653 & -.0618 & $-.286 * * *$ & $.0436 * *$ \\
\hline & $(0.03)$ & $(4.22)$ & $(-0.54)$ & $(-0.08)$ & $(-2.63)$ & $(2.41)$ \\
\hline \multirow[t]{2}{*}{ Follow } & -.722 & $2.6 * * *$ & $-.0547^{*}$ & -.00649 & $-.0064 * *$ & $.00174 * * *$ \\
\hline & $(-1.62)$ & $(8.67)$ & $(-1.89)$ & $(-0.24)$ & $(-2.26)$ & (3.58) \\
\hline \multirow[t]{2}{*}{ Volatility } & .08 & $.184 * *$ & -.00774 & $-.012 * *$ & .00045 & $.000266 * * *$ \\
\hline & (1.10) & $(2.52)$ & $(-1.31)$ & $(-1.98)$ & (1.32) & $(2.76)$ \\
\hline \multirow{2}{*}{ Size } & $6.65 * * *$ & $2.83 * *$ & -.0164 & -.161 & -.00856 & $.00587 * * *$ \\
\hline & $(4.97)$ & (2.38) & $(-0.14)$ & $(-1.48)$ & $(-0.88)$ & (3.02) \\
\hline \multirow[t]{2}{*}{ Tier1 } & $337 * * *$ & $-292 * * *$ & $14.2 * *$ & $21.8^{* * *}$ & $-.912 *$ & $-.552 * * *$ \\
\hline & $(4.43)$ & $(-4.81)$ & $(2.16)$ & $(3.47)$ & $(-1.80)$ & $(-5.78)$ \\
\hline \multirow[t]{2}{*}{ ROE } & -11.8 & $-65 * * *$ & $3.01 * * *$ & $3.07 * *$ & .0377 & -.0222 \\
\hline & $(-0.88)$ & $(-6.79)$ & $(2.82)$ & $(2.47)$ & $(0.51)$ & $(-1.28)$ \\
\hline \multirow[t]{2}{*}{ MB } & .733 & -3.31 & -.278 & .3 & .00323 & -.00282 \\
\hline & $(0.29)$ & $(-1.49)$ & $(-1.28)$ & (1.29) & $(0.19)$ & $(-0.80)$ \\
\hline \multirow[t]{2}{*}{$\Delta$ Earnings } & -.0153 & $-.282 * *$ & -.0062 & .00569 & .00119 & -.000125 \\
\hline & $(-0.10)$ & $(-2.07)$ & $(-0.50)$ & $(0.33)$ & $(1.50)$ & $(-0.67)$ \\
\hline \multirow[t]{2}{*}{ IV quarter } & $-7.8 * * *$ & $-10.4 * * *$ & $1.37 * * *$ & $2.46^{* * *}$ & $-.113 * * *$ & $-.0103 * * *$ \\
\hline & $(-3.99)$ & $(-5.40)$ & $(6.65)$ & $(9.70)$ & $(-7.38)$ & $(-3.11)$ \\
\hline \multirow[t]{2}{*}{ Financial } & -3.47 & 2.96 & -.181 & -.165 & .0164 & .0047 \\
\hline & $(-0.92)$ & $(0.97)$ & $(-0.76)$ & $(-0.73)$ & (0.99) & (1.07) \\
\hline Year & Yes & Yes & Yes & Yes & Yes & Yes \\
\hline chi2 & 135.3 & 858.4 & 130.0 & 202.9 & 125.0 & 424.6 \\
\hline N. of cases & 649 & 649 & 649 & 649 & 649 & 649 \\
\hline N. of banks & 131 & 131 & 131 & 131 & 131 & 131 \\
\hline average group size & 4.95 & 4.95 & 4.95 & 4.95 & 4.95 & 4.95 \\
\hline
\end{tabular}

Std. Err. adjusted for clusters

$\mathrm{t}$-statistics in parentheses

$* \mathrm{p}<0.10, * * \mathrm{p}<0.05, * * * \mathrm{p}<0.01$

See Table 1 for variables definitions 
Table 10

Fair Value non-recurring (2008.1-2009.2) and the Information Properties of Analysts' Forecasts

\begin{tabular}{|c|c|c|c|c|c|c|}
\hline & $\begin{array}{c}(1) \\
\text { accuracy }\end{array}$ & $\begin{array}{c}(2) \\
\text { dispersion }\end{array}$ & $\begin{array}{l}\text { (3) } \\
\mathrm{h}\end{array}$ & $\begin{array}{l}\text { (4) } \\
\mathrm{S}\end{array}$ & $\begin{array}{l}\text { (5) } \\
\rho\end{array}$ & $\begin{array}{c}\text { (6) } \\
\text { U-SE }\end{array}$ \\
\hline \multirow[t]{2}{*}{ CONSTANT } & -3.86 & $62.6^{* * *}$ & .67 & -.224 & $1.1 * * *$ & $.106 * * *$ \\
\hline & $(-0.39)$ & $(5.71)$ & $(0.79)$ & $(-0.24)$ & (16.76) & $(6.81)$ \\
\hline \multirow[t]{2}{*}{ FV } & $6.88 * * *$ & -5.42 & -.064 & $.599 * * *$ & -.0722 & $-.0123 * *$ \\
\hline & (3.31) & $(-1.61)$ & $(-0.25)$ & $(2.66)$ & $(-1.56)$ & $(-2.45)$ \\
\hline \multirow{2}{*}{$\mathrm{FV}_{\text {non-recurring }}$} & $-693 * * *$ & $498 * * *$ & $-18.3^{*}$ & -14.2 & $1.52 * *$ & $.704 * * *$ \\
\hline & $(-6.02)$ & (3.68) & $(-1.66)$ & $(-1.33)$ & (2.43) & (3.61) \\
\hline \multirow[t]{2}{*}{ Loss } & -352 & 509 & -58 & 17.8 & 3.12 & .365 \\
\hline & $(-0.42)$ & $(0.60)$ & $(-0.91)$ & $(0.24)$ & $(0.82)$ & $(0.32)$ \\
\hline \multirow[t]{2}{*}{ Follow } & -.549 & $2.5 * * *$ & $-.053 * *$ & .0241 & $-.00789 * * *$ & $.00114 * *$ \\
\hline & $(-1.24)$ & (6.90) & $(-2.03)$ & $(0.84)$ & $(-2.81)$ & (2.29) \\
\hline \multirow[t]{2}{*}{ Volatility } & .0815 & .116 & -.00495 & -.00468 & .000353 & .000161 \\
\hline & $(1.35)$ & $(1.50)$ & $(-0.93)$ & $(-0.76)$ & $(0.97)$ & (1.64) \\
\hline \multirow[t]{2}{*}{ Size } & $6.44 * * *$ & $3.32 * *$ & .0432 & -.153 & -.0025 & $.00761 * * *$ \\
\hline & $(4.50)$ & (2.30) & $(0.40)$ & $(-1.36)$ & $(-0.25)$ & $(3.75)$ \\
\hline \multirow[t]{2}{*}{ Tier1 } & $380 * * *$ & $-298 * * *$ & $15.5^{* * *}$ & $17.2 * * *$ & $-.867 *$ & $-.545 * * *$ \\
\hline & $(5.57)$ & $(-4.40)$ & $(2.58)$ & $(2.69)$ & $(-1.75)$ & $(-5.58)$ \\
\hline \multirow[t]{2}{*}{ ROE } & -6.62 & $-65.2 * * *$ & $2.85^{* * *}$ & .719 & .101 & -.0221 \\
\hline & $(-0.51)$ & $(-4.97)$ & $(3.06)$ & $(0.67)$ & (1.19) & $(-1.23)$ \\
\hline \multirow[t]{2}{*}{ MB } & 3.92 & $-4.31 *$ & -.211 & .245 & -.0104 & -.00268 \\
\hline & (1.51) & $(-1.68)$ & $(-1.02)$ & $(1.02)$ & $(-0.59)$ & $(-0.75)$ \\
\hline \multirow[t]{2}{*}{$\Delta$ Earnings } & -.078 & -.159 & -.0127 & .00241 & .000615 & .0000305 \\
\hline & $(-0.48)$ & $(-1.03)$ & $(-1.03)$ & $(0.19)$ & $(0.77)$ & $(0.17)$ \\
\hline \multirow{2}{*}{ IV quarter } & $-9.17 * * *$ & $-10.7 * * *$ & $1.53^{* * *}$ & $1.78 * * *$ & $-.108 * * *$ & $-.0129 * * *$ \\
\hline & $(-4.18)$ & $(-4.75)$ & (7.59) & $(9.07)$ & $(-6.78)$ & $(-3.77)$ \\
\hline \multirow[t]{2}{*}{ Financial } & $-5.37 *$ & $7.75^{* *}$ & $-.448^{* * *}$ & -.167 & .00785 & $.00934 * *$ \\
\hline & $(-1.78)$ & $(2.29)$ & $(-2.11)$ & $(-0.66)$ & $(0.47)$ & $(2.06)$ \\
\hline Year & Yes & Yes & Yes & Yes & Yes & Yes \\
\hline chi2 & 272.1 & 476.9 & 124.1 & 143.7 & 103.9 & 355.6 \\
\hline N. of cases & 606 & 606 & 606 & 606 & 606 & 606 \\
\hline N. of banks & 131 & 131 & 131 & 131 & 131 & 131 \\
\hline average group size & 4.63 & 4.63 & 4.63 & 4.63 & 4.63 & 4.63 \\
\hline
\end{tabular}

Std. Err. adjusted for clusters

$\mathrm{t}$-statistics in parentheses

No change without fv_tot

$* \mathrm{p}<0.10, * * \mathrm{p}<0.05, * * * \mathrm{p}<0.01$

See Table 1 for variables definitions 